\title{
ON A COLLECTION OF ISAEIDAE (CRUSTACEA, AMPHIPODA) FROM THE SOUTHERN INDIAN REGION
}

\author{
by \\ P. RABINDRANATH \\ Marine Biology Laboratory, University of Kerala, Trivandrum-7, Kerala, India 1)
}

\begin{abstract}
Nine species of gammaridean amphipods, belonging to the family Isaeidae, are fully described and figured. Eight of these were collected from typical marine locations on the East and West coast of South India and one, namely Photis digitata K. H. Barnard, 1935, was obtained from a brackish water lake on the West coast of peninsular India between $9^{\circ} 7^{\prime}$ and $9^{\circ} 16^{\prime} \mathrm{N}$ and $76^{\circ} 20^{\prime}$ and $76^{\circ} 28^{\prime} \mathrm{E}$. Five of the species described are already known from the Indian coasts; one species, Eurystheus digitatus Schellenberg, 1938, is a new record for the region; two others (Microprotopus bicuspidatus and Eurystheus anomalus) are new to science. Until more materials become available, the last species included in this report is provisionally assigned to the genus Megamphopus Norman and is described without a specific name.
\end{abstract}

\section{INTRODUCTION}

The materials on which this short report is based were collected chiefly during two collection trips, one to Mandapam (Gulf of Mannar) and another to Thankasserry (Quilon, Kerala).

Analysis of the bottom samples taken from the Kayamkulam backwaters, a brackish water lake in Kerala, also provided a small collection of amphipods. Mandapam is an ideal locaiity for collecting amphipods since, within a short distance one encounters various types of habitats like sandy or muddy flats, submerged boulders overgrown with algae and hydroids, and above all extensive coral reefs. Further, on the continental flat, within a radius of about 3 to 4 miles, there is a belt of small islands with an abundant growth of corals and sponges which provide the substrate for epifaunal populations. At Thankasserry, the intertidal area is strewn with laterite boulders

1) Present address: Sree Vilas, Mavelikkara-1, Kerala, India bearing a luxuriant overgrowth of algae. In both localities gammaridean amphipods are very abundant. The floor of the Kayamkulam lake is formed of fine sand and clay.

The type specimens are deposited at the Marine Biology Laboratory, University of Kerala, Trivandrum - 7, Kerala; representative samples of the material treated in this paper in the Zoölogisch Museum Amsterdam.

\section{TAXONOMY}

Suborder GAMMARIDEA, Family Isaeidae

Genus Microprotopus Norman, 1867

Microprotopus bicuspidatus sp. n. Figs. 1-2.

Material. - 13 males and 8 females were collected from among algal growths on submerged rocks at Pamban (near Mandapam), Gulf of Mannar.

Male. - Length $1.9 \mathrm{~mm}$. Body moderately stout and irregularly pigmented; cephalon longer than first 2 peraeon segments combined and nonrostrate; ocular lobes angularly produced, eyes prominent, large and placed a little to the rear of the pointed apex of each lobe, with median darker and peripheral lighter ocelli. Peraeon segments subequal in length and moderately deep. Pleon slender and poorly formed, segments 1 to 3 progressively increasing in length, 1st very shallow, 2nd and 3rd subequal in depth, lower borders of the anterior two slightly convex, that of $3 \mathrm{rd}$ nearly straight, postero-inferior angles rounded in all and defined by a shallow notch above, carrying a setule, distal borders bulging. Fourth pleon segment $3 / 4$ as long as and nearly as deep as 3rd, 5th and 6th very small and subequal in length, together shorter than 4th. Telson entire, small, broader than long, distally rounded and with a pair of blunt, lateral prominences as in $M$. longimanus 


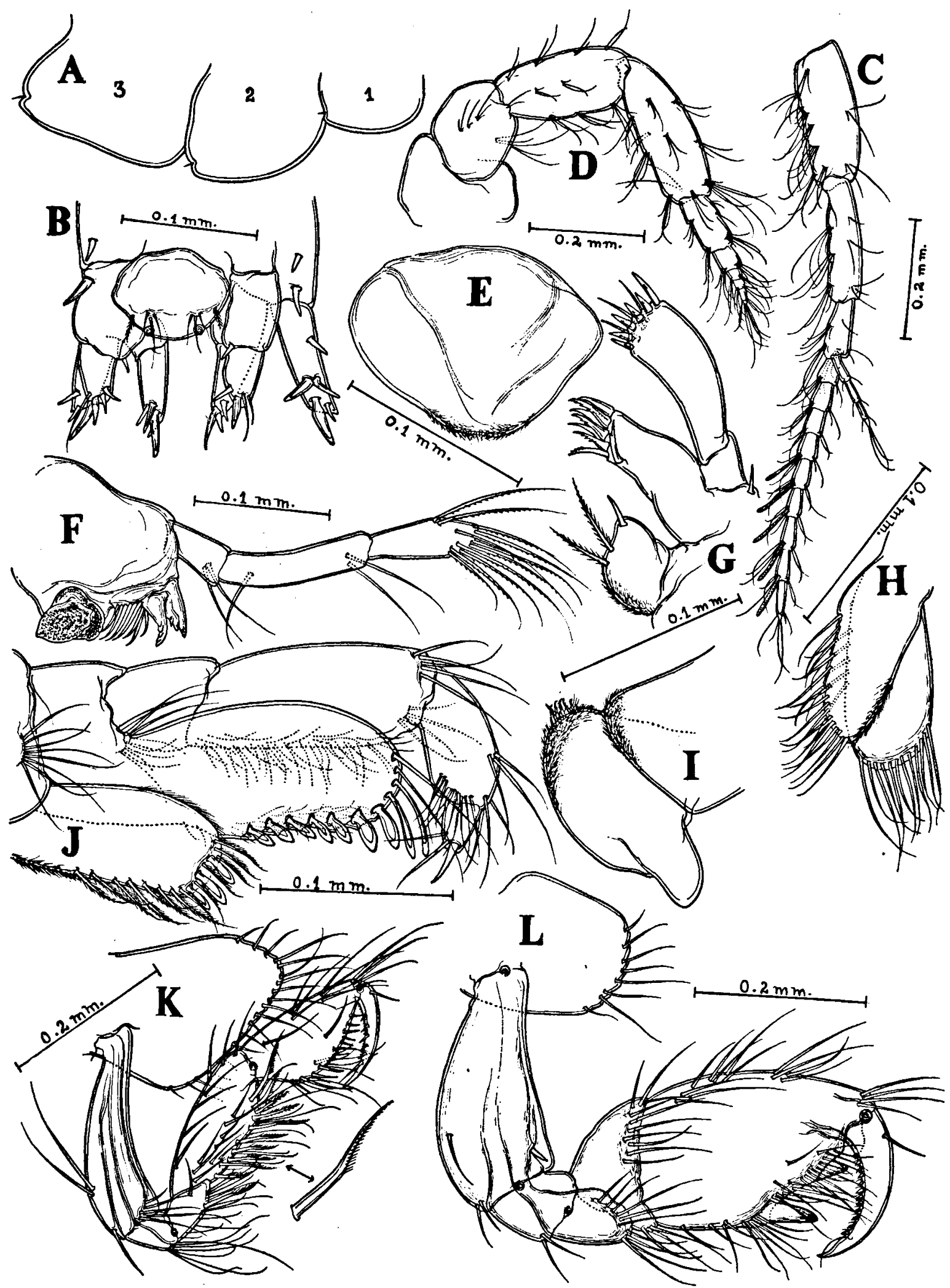

Fig. 1. Microprotopus bicuspidatus sp.n., holotype, $\delta$, $1.9 \mathrm{~mm}$. A, pleon epimera 1 to 3 (not drawn to scale); B, telson with uropods 2 and 3; C, antenna 1; D, an- tenna 2; E, upper lip; F, mandible; G, maxilla 1; H, maxilla 2; I, lower lip; J, maxilliped; K, gnathopod 1; L, gnathopod 2 . 
(Chevreux, 1887), each having 3 setules at base, lateral margin with a plumose setule at about its middle. Coxae not strongly setiferous and only moderately deep. First coxal plate distally expanding, lower part of front margin faintly crenate, inferior border nearly straight and with a row of long setae; 2nd to 4th subsimilar, rotundo-quadrate, deeper than broad, inferior margins convex and with a few setae. Fifth and 6th coxal plates bilobed, anterior lobe of 5th very deep, reaching beyond the middle of basis, narrowly rounded distal margin with a row of setules. Seventh coxal plate very small and nearly oval.

Antennae not very long and not very unequal in length, 2nd stouter. First segment of peduncle of antenna 1, a little longer than and nearly twice broader than 2 nd, 3rd segment small, about $1 / 2$ as long as 2 nd, flagellum shorter than peduncle and 10-segmented. Lower borders of all segments more setose, distal segments of flagellum with a few olfactory setae. Accessory flagellum as long as first 3 flagellar segments combined, slender and 4-segmented. Third segment of peduncle of 2nd antenna almost rounded, 4th shorter than 5th, flagellum shorter than last peduncular segment and 6-segmented, 1st segment as long as next 5 combined. Peduncle and flagellum sparsely setose.

Upper lip distally narrowing and slightly hirsute. Incisor process of mandible tridentate and moderately chitinized, lacinia mobilis well developed and dentate, spine row consisting of 7 simple spines, molar smooth and of moderate size. First segment of palp $1 / 2$ length of 2 nd, 2 nd long and slightly bent in the middle, 3 rd shorter than 2 nd, broader distally, distal part carrying a brush of long, pectinate spine-setae. Inner lobe of 1st maxilla almost triangular, its inner margin bulging and hirsute, with 2 pectinate spine-setae in the upper half, narrowly rounded apex of the lobe armed with 8 barbed, spine-teeth, palp reaching beyond distal margin of outer lobe, 1st segment small, 2nd distally expanding, truncate apical margin carrying 6 spine-teeth and a variable number of submarginal spine-setae. Lobes of 2 nd maxilla subsimilar, uniformly convex inner margin of inner lobe armed with long spine-setae, distal part of outer border slightly hirsute, outer lobe nearly rectangular and with a row of spinesetae on convex distal border. Inner lobes of lower lip well developed, nearly triangular, narrowly rounded distal part hirsute, outer lobes broad, each distally rounded and hirsute, and with a group of spine-like appendages at the apex.
Mandibular processes small and blunt. Maxilliped well-developed, inner lobe rectangular, reaching beyond 1st endopod segment, truncate distal margin armed with 3 flat, club-shaped spine-teeth and a few pectinate spine-setae, latter extending along inner margin. Outer margin convex and its upper half hirsute. Outer lobe large, oval, nearly reaching distal border of 2 nd endopod segment, inner margin broadly crenate and armed with a row of 7 graduated, flat spine-teeth, which on the rounded distal margin appear setiform. Outer margin convex and unarmed. Endopod stout, 1st segment nearly squarish, $1 / 2$ as long as 2 nd, 2 nd rectangular, elongated and fringed with setae on inner margin, 3rd broadly oval, $1 / 4$ longer than 1 st, distally armed with long spine-setae, 4th segment short, $1 / 3$ length of $3 \mathrm{rd}$, tipped with a strong nail, about as long as the segment and a few spinesetae.

First gnathopod smaller than 2nd, but more setose; basis proximally narrow, as long as merus and carpus combined, inner margin with 2 or 3 very long setae; ischium small, apex of inner margin carrying a cluster of long setae. Merus roughly triangular, distally produced and nearly pointed, smoothly convex inner border armed with spinesetae, some of them characteristically pectinate on the distal half; carpus elongate, broadening distally, outer margin gently curving and sparsely setose, inner margin straight up to $3 / 4$ of its length from base, then dipping inwards and strongly armed with pectinate spine-setae; propodus shorter than carpus, broadest in the middle, outer margin straight, with fascicles of spine-setae on distal half, inner margin continuous with palm, forming a prominent bulge in the middle, spiny and setose, 1 or 2 spines at the rounded angle being larger than the rest; dactylus about $3 / 4$ shorter than propodus, very slightly curved, ending in a small nail, inner border faintly serrate and with a row of spines, the last spine largest. Basis of 2nd gnathopod much broader distally, shorter than propodus and with a submarginal outer distal spine; ischium nearly squarish; merus longer than ischium, with a cluster of simple setae on the produced rounded apex; carpus cup-shaped, inner margin very short and lobe-like, outer convex; propodus massive, subrectangular, outer and inner borders subparallel, former very slightly convex and twice as long as latter, both sparsely armed with simple setae, inner ending in a stout, thumblike defining tooth; palm oblique, setiferous and with a tooth-like prominence nearer to the hinge; 


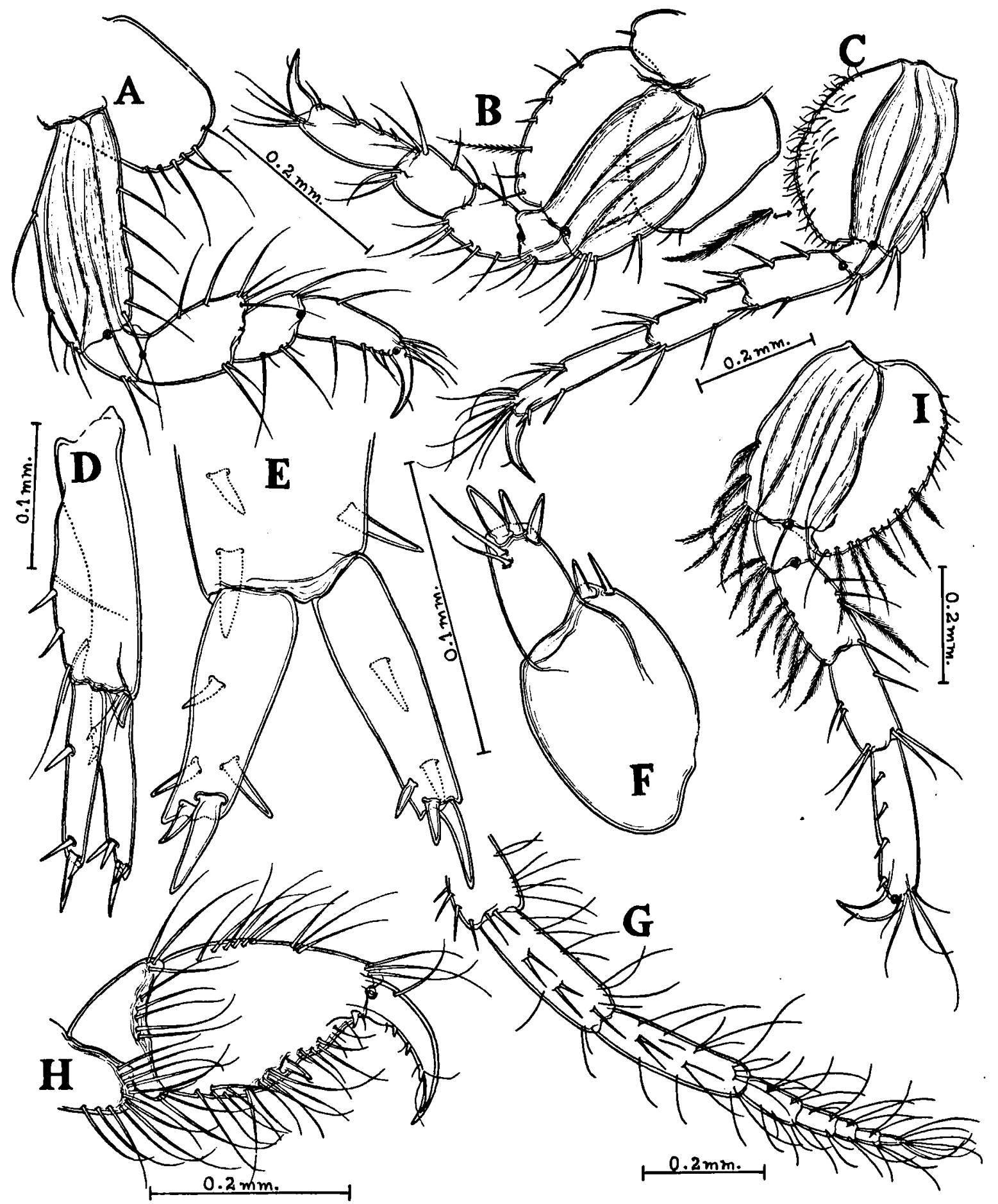

Fig. 2. Microprotopus bicuspidatus sp.n. A-F, holotype, o, $1.9 \mathrm{~mm}$ : A, peraeopod 2; B, peraeopod 3; C, peraeo- pod 5; D, uropod 1; E, uropod 2; F, uropod 3. G-I, $\%, 2.1 \mathrm{~mm}$ : G, antenna 2; H, gnathopod 2 (segments 4 to 7 ); I, peraeopod 4 . 
dactylus stout, strongly curved and reaching the beginning of the palmar border, its nail slightly swollen at base and the inner margin armed with a row of small spine-teeth. Peraeopods 1 and 2 similar, basis not expanded, as long as next 3 segments combined, ischium small, merus distally expanding, $1 / 2$ the length of basis, carpus slender, as long as ischium, propodus narrowing distally, subequal to merus in length, dactylus slightly curved and about $1 / 3$ shorter than propodus. Peraeo. pods 3 to 5 successively increasing in length, last pair extending well beyond uropods, basis of peraeopod 3 very broad, rest of the appendage somewhat flattened and armed with slender spinesetae, dactylus strong as in peraeopod 1.

Basis of peraeopods 4 and 5 less expanded, outer margin convex and armed with short plumose setae, rest of the appendage rather slender and armed with sparsely distributed stiff spines.

Peduncle of uropod 1 much longer than rami, distal border carrying a stout, tooth-like prominence in its lower half, rami subequal, with spiny apices. Uropod 2 much shorter than uropod 1, apices of rami subtruncate. Uropod 3 uniramous, peduncle stout, roughly oval, slightly less than twice the length of ramus, inner margin with 2 prominent apical spines, ramus narrowing towards apex and tipped with 3 stout spines and 2 submarginal setules.

Female. - Length $2.1 \mathrm{~mm}$. Slightly larger than male and more strongly pigmented. Antennae subequal in length, 2nd stout, its flagellum longer than the ultimate peduncular segment. Gnathopod 2 different from that of male: spine defining palm comparatively small and the spine near the hinge of dactylus absent; propodus roughly triangular; inner margin of dactylus poorly spiny.

Remarks. - Including the present species, the genus Microprotopus contains 6 species. Of these, $M$. emissitius (Dana, 1852) and $M$. hirsuticornis (Dana, 1852) are inadequately described, so that a comparison is not possible. Of the other 4 species, $M$. maculatus Norman, 1867 and $M$. longimanus (Chevreux, 1887) differ from the present species in the presence of 3 teeth on the palmar border of the 2nd gnathopod of the male. As in the new species, $M$. raneyi Wigley, 1966, has only 2 teeth and judging by the nature of the 2 nd gnathopod, they are more closely related. However, in $M$. raneyi the teeth are close to one another and placed very close to the hinge with the dactylus.
Also, the dactylus is very long, almost reaching the base of the propodus. On the other hand, in $\boldsymbol{M}$. bicuspidatus sp. $\mathrm{n}$. the 1st tooth is in the middle of the inner side of the propodus and the dactylus reaches only as far as the beginning of the palmar border.

In spite of the differences in the armature of the propodus of gnathopod 2 , the present species shows overall resemblance to $M$. longimanus. But, in $M$. longimanus the accessory flagellum of antenna 1 is only 2 -segmented, while in the new species it is 4-segmented. The flagellum of antenna 2 is not more than 3-segmented in $M$. longimanus, wheras it is 6-segmented in $M$. bicuspidatus.

Genus Photis Krøyer, 1842

Photis longimanus Walker, 1904. Figs. 3-4.

Photis longimanus Walker, 1904: 286-287, pl. 7 fig. 44; K. H. Barnard, 1916: 244-247; Schellenberg, 1925: 175; K. H. Barnard, 1940: 479; J. L. Barnard, 1962: 27-29; Nayar, 1965: 158, fig. 9 f-g.

Material. - 2 males and 22 females were collected from among weed encrusted rocks in the littoral area at Pamban (Gulf of Mannar).

Male. - Length $3.0 \mathrm{~mm}$. Body rather slender and smooth; cephalon about as long as first 2 thoracic segments combined; ocular lobes projecting and narrowly rounded in front, reaching almost the middle of the 1st peduncular segment of 1 st antennae; eyes large, rounded, with reddish-brown peripheral and dark central regions occupying almost the entire lobe. Peraeon segments gradually increasing in size and depth towards the hind end; pleon smooth, 1st segment smaller than 2 nd or 3 rd, with rounded postero-lateral corners, segments 2 and 3 subsimilar, postero-lateral corners slightly produced, pleon segments 4 to 6 distinct, successively increasing in length backwards, 4th with a dorsal depression close to the proximal end. Telson small, broader than long, subtriangular, with a small projection on each lateral margin distally, bearing a spine and a seta. Anterior 4 coxal plates subsimilar, oblong and as deep as corresponding segments, remaining pairs small, 5th and 6th bilobed, with rounded lobes, 7th nearly rounded.

Antennae subequal in length, $1 / 3$ as long as the body and sparsely setose. First peduncular segment of antenna 1 twice as thick as 2nd, but shorter, subequal to $3 \mathrm{rd}$ in length; flagellum 6-segmented; accessorry flagellum scale-like, with 3 small apical 
P. RABINDRANATH - SOUTHERN INDIAN ISAEIDAE

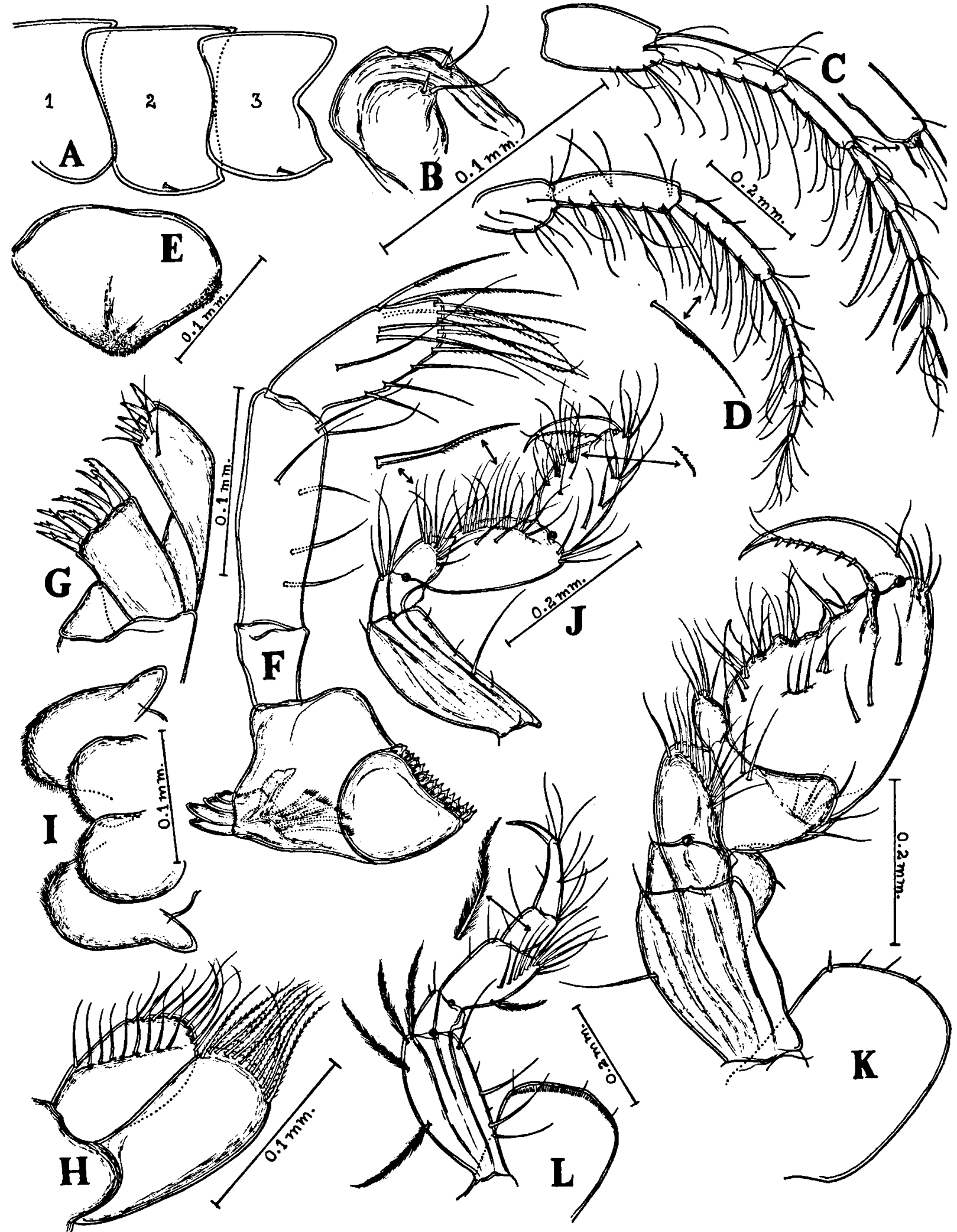

Fig. 3. Photis longimanus Walker, 1904, ô, $3.0 \mathrm{~mm}$. A, pleon epimera 1 to 3 (not drawn to scale); B, telson; C, antenna 1; D, antenna 2; E, upper lip; F, mandible;
G, maxilla 1; H, maxilla 2; I, lower lip; J, gnathopod 1; K, gnathopod 2; L, peraeopod 1. 
setae. Third segment of peduncle of 2 nd antenna nearly $1 / 2$ as long as 4 th, 5 th segment subequal to and more slender than 4th; flagellum 6-segmented.

Mouth parts and maxillipeds typical of the genus.

Gnathopod 1 much smaller than gnathopod 2; basis as long as merus and carpus combined and nearly as wide as carpus at the distal end; merus slightly produced over the base of carpus, with a subdistal circlet of pectinate setae; carpus oblong, longer than propodus, inner margin with a fringe of pectinate setae; propodus roughly oval; palm not distinct, finely serrate and with a spine. Dactylus curved, more than $1 / 2$ length of propodus, with a proximal inner declivity and a toothed inner border. Basis of gnathopod 2 stout, distal anterior border produced into a rounded lobe; merus oblong, with an oblique distal row of setae; carpus much broader than long, overlapping propodus and with an inner lobe projecting between the adjacent segments and bearing a few apical setae. Propodus elongate-triangular, outer border smooth, inner very short, ending in a strongly projecting process, palmar border irregular, with 2 high projections alternating with 2 low ones. Dactylus stout, curved, reaching the proximal process on propodus, armed on inner margin with a few small teeth and spinules. Peraeopods 1 and 2 slender, subsimilar; merus expanded distally; carpus about $1 / 2$ as long as merus and slightly immersed in it; propodus narrow, nearly as long as merus; dactylus slender and curved. The expanded distal end of merus in peraeopod 1 with an oblique row of plumose setae on inner surface. Basis of peraepod 3 very much expanded, roughly oval, merus and carpus about the same size, together as long as propodus, latter with 2 spines on inner border; dactylus small and curved like a claw. Peraeopod 4 similar to peraeopod 3, but longer and with less expanded basis. Peraeopod 5 longest; basis nearly oblong; merus and carpus together as long as propodus; propodus slightly widening distally; dactylus strong, curved and $1 / 2$ as long as propodus. Peraeopod 3 in live specimens upturned, last 2 pairs directed backwards, all sparsely setose and almost devoid of spines.

Uropod 1 longer than uropods 2 and 3, rami subequal in length, about $1 / 2$ as long as peduncle; outer ramus with serrate upper margin and armed with 2 spines, one apical and the other about in the middle; inner ramus with a single apical spine, peduncle with 6 spines on serrate upper bor- der. Uropod 2, 2/3 as long as uropod 1; peduncle about the same length as inner ramus; outer ramus slightly shorter than inner, both with a median and an apical spine. Uropod 3 with a rudimentary inner ramus carrying a small apical spine, outer ramus as long as peduncle but narrowing distally, apical segment with 2 long, slender setae.

Female. - Length $2.9 \mathrm{~mm}$. Closely resembling male, except in the gnathopods. First gnathopod subsimilar to that of male, but more slender and without any spine on palm. Basis of 2 nd gnathopod without outer distal expansion; carpus cupshaped, inner border without any projecting lobe; propodus oblong-oval, inner margin about as long as palm, distally not produced, but raised into a slight projection, followed by the usual defining spine; palmar border with a median low projection.

Remarks. - According to Walker (1904), this spscies can be distinguished by the peculiar form of the wrist and hand of the 2nd gnathopods. The carpus, as observed by Walker, forms a prominent inner lobe at the base of propodus, and the propodus has "a strong blunt tooth near the base of the inner surface, the hind margin divided into 3 nearly equal concave spaces by this and 2 other teeth, the middle one being the smallest". This description applies perfectly to my specimens. Nevertheless, his figure of the 2nd gnathopod of the male shows the 3rd segment as produced into a large lobe, making it much broader than the basis. This is obviously a mistake, Walker evidently mistook the lobe-like expansion of the basis to be that of the ischium.

K. H. Barnard (1916) has given a lengthy description of specimens collected in South African waters. His description of the male 2nd gnathopod as having an oblique palm shorter than the hind margin is puzzling. If this is the condition in his specimens, they are certainly different from Walker's specimens. Also, he has described the 3rd segment of this appendage as having a rounded lobe on the lower inner surface. This is absent in Walker's specimens as well as mine. Probably, as stated by him, the allegedly immature male in Barnard's collection may represent the true form, but unfortunately he has not illustrated it.

This species does not seem to have been illustrated in detail, though there are several descriptions pointing out its differences from the allied 


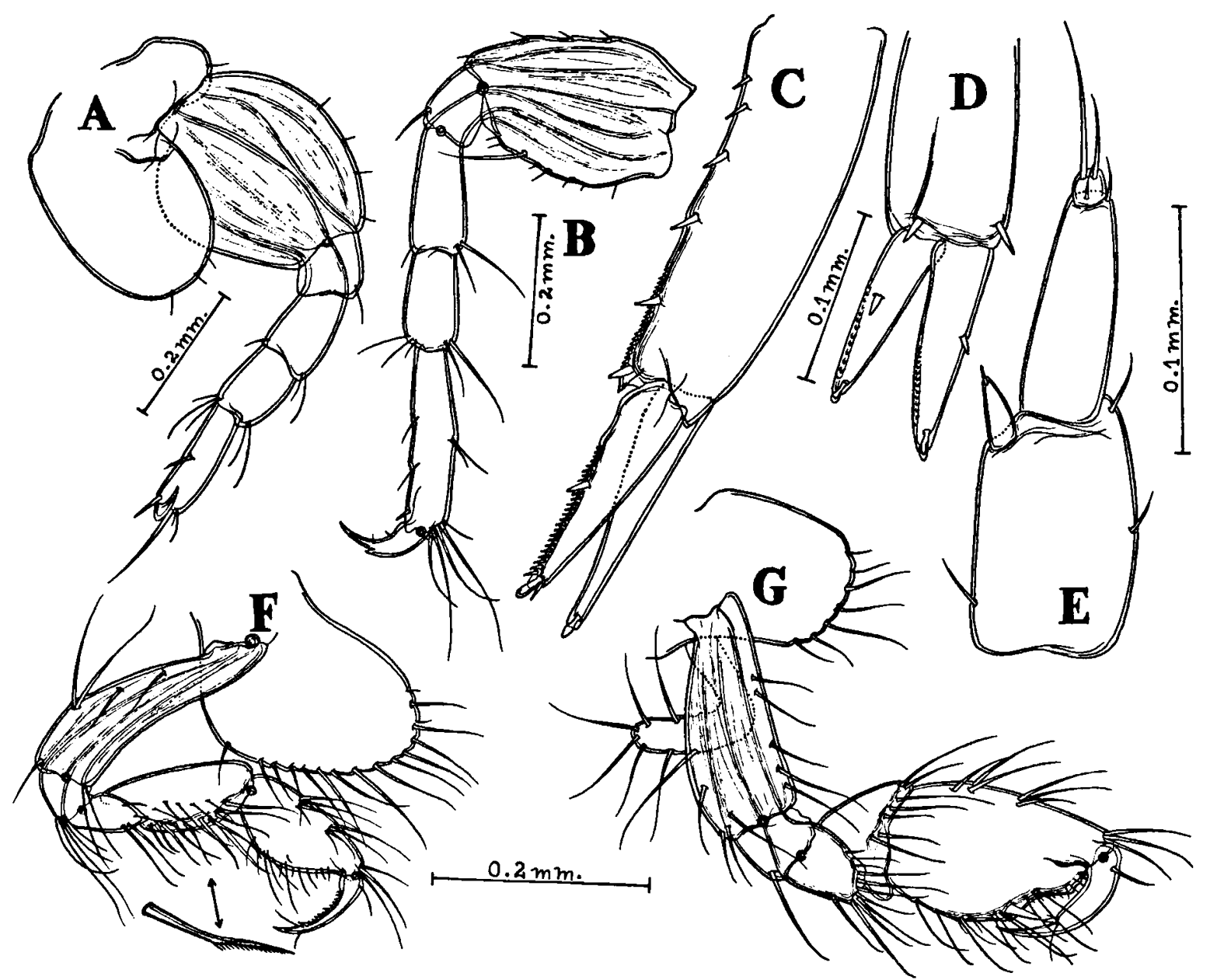

Fig. 4. Photis longimanus Walker, 1904. A-E, ô, 3.0 $\mathrm{mm}$ : A, peraeopod 3; B, peraeopod 5; C, uropod 1; D, uropod 2; E, uropod 3.

F-G, \%, $2.9 \mathrm{~mm}$ : F, gnathopod 1; G, gnathopod 2 . species. It is hoped that the accompanying illustrations will remedy this defect and help future workers in arriving at a correct estimation of the species easily.

Photis digitata K. H. Barnard, 1935. Fig. 5.

Photis longicaudata (non Bate \& Westwood) Chilton, 1921: 554, fig. 12.

Photis digitata K. H. Barnard, 1935: 302-303; Nayar, 1959: 35, pl. 12 figs. 8-24; J. L. Barnard, 1962: 27-29.

Material. - 10 males and 13 females were collected from the Kayamkulam lake, in Kerala.

Male. - Length $2.8 \mathrm{~mm}$. Body rather slender, smooth; cephalon moderately produced, a little longer than first 2 peraeon segments combined; ocular lobes projecting, reaching end of 1st peduncular segment of 2 nd antenna; eyes large, round- oval and black. Anterior 4 peraeon segments subsimilar, remaining ones deeper. Pleon smooth, first 3 segments more or less of equal depth, 3rd longer, 1st with rounded postero-lateral corners, segments 4 to 6 distinct, successively decreasing in depth towards posterior end. Telson triangular, apically angular, with 3 pairs of subapical setae. Anterior 4 pairs of coxae oblong, forwardly directed, distally narrower and attenuated, twice as deep as the corresponding segments, 3rd deeper than the rest and moderately setiferous along free margins, 5th and 6th pairs bilobed, former with large obliquely rounded front lobes, last coxa nearly rounded.

Antenna 1 slightly longer than antenna 2; 1st peduncular segment thick, subequal in length to 3rd; 2nd segment $11 / 2$ times the length of 1 st, flagellum 5- to 7-segmented. Peduncle of 2 nd an- 


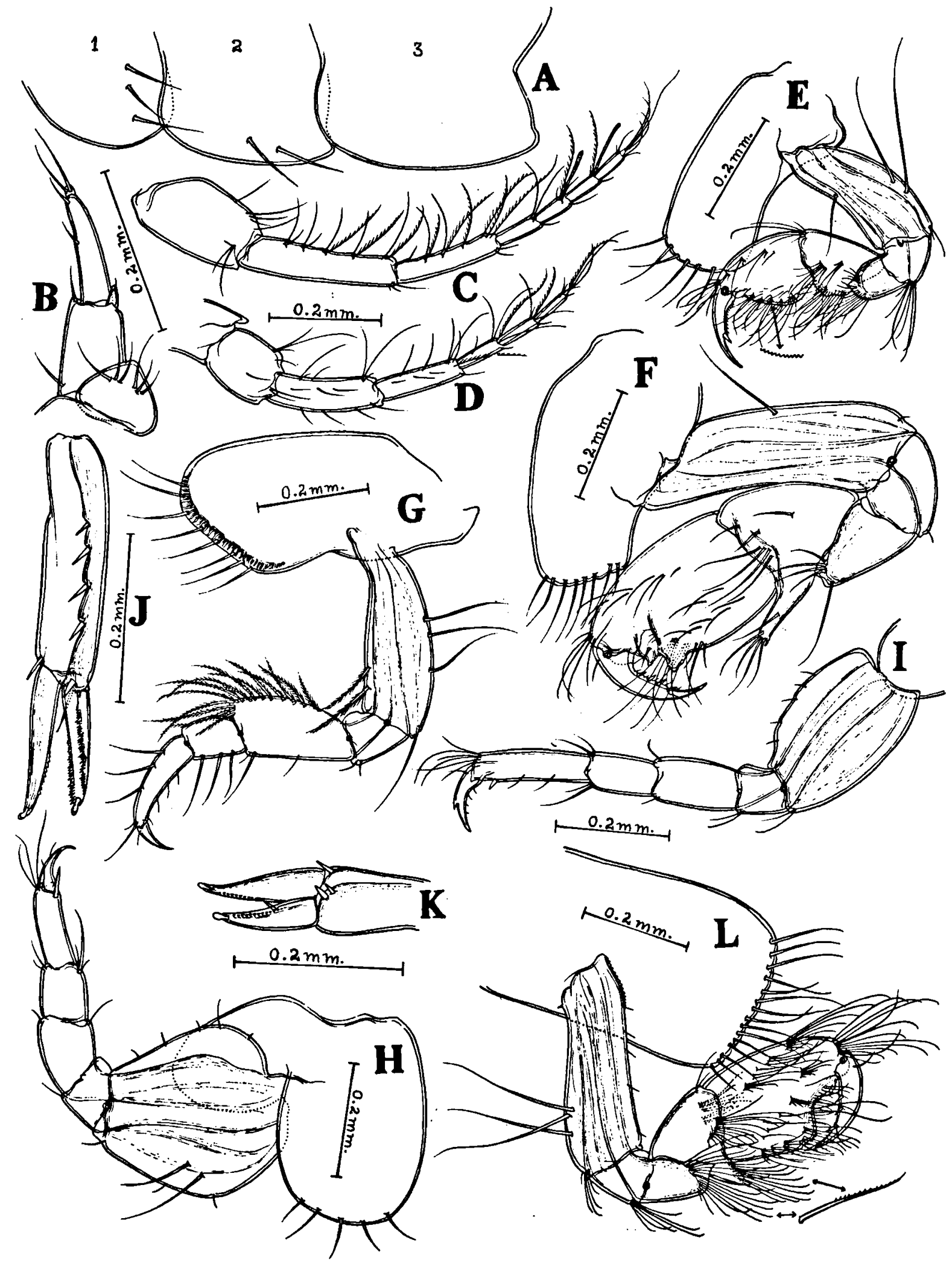

Fig. 5. Photis digitata K. H. Barnard, 1935. A-K, ô, $2.8 \mathrm{~mm}$ : A, pleon epimera 1 to 3 (not drawn to scale); $B$, telson with uropod $3 ; C$, antenna $1 ; D$, antenna 2 ;
E, gnathopod 1; F, gnathopod 2; G, peraeopod 1; $\mathrm{H}$, peraeopod 3; I, peraeopod $5 ; \mathrm{J}$, uropod $1 ; \mathrm{K}$, uropod 2. L, $\$, 2.7 \mathrm{~mm}$ : gnathopod 2 . 
tenna with 4th segment longest, flagellum 4- to 6segmented and slightly longer than 4 th peduncular segment.

Mouth parts and maxillipeds typical of the genus.

First gnathopod much smaller than 2nd; basis short and thick; ischium and merus subequal; carpus roughly triangular and nearly as long as propodus; palm ill-defined, serrate, oblique and setose; dactylus about as long as propodus, curved and armed with 1 small inner tooth and a row of fine setules. Second gnathopod massive, with comparatively long basis; carpus large and triangular, produced into a prominent, digitiform apically setose process, reaching a third of the length of the inner margin of propodus; propodus long-ovate; palm as such not well defined, oblique, palmar border produced into 2 unequal prominences; dactylus about $1 / 2$ length of propodus, curved as in gnathopod 1, with small evenly arranged spines on inner border. Peraeopod 1 longer than peraeopod 2; basis broader towards the distal end, longer than next 2 segments combined; merus rather long, armed with long plumose setae on outer margin; carpus roughly squarish, $1 / 2$ length of merus; propodus long, narrowing distally; dactylus weak and slightly curved. Peraeopod 2 very much like peraeopod 1, but without the long setae on the outer margin of merus. Peraeopod 3 shorter; basis broad, narrowing towards distal end; following 3 segments subequal; propodus twice as long as wide, with a strong spine at inner distal end; dactylus slightly curved. Peraeopods 4 and 5 almost of the same length, but longer than 3rd; basis in both much less expanded than in 3rd peraeopod; dactylus with a small outer tooth in the middle.

Uropod 1 extending back as far as uropod 3; peduncle thick and longer than rami, outer edge armed with 5 strong lateral spines and inner edge with 1 terminal spine; inner and outer margins of outer ramus and outer margin of inner ramus crenulate. Uropod 2 almost as long as peduncle of uropod 1; outer ramus shorter than inner, with a spine in the middle of the inner margin; inner margin of outer ramus and outer margin of inner ramus feebly crenulate in the distal half; peduncle with 2 spines on outer edge and a terminal one on inner distal end. Uropod 3 about the same length as uropod 2; outer ramus slender, longer than peduncle; 2 nd segment very minute and armed with 2 long, apical setae, basal segment with 2 short setae on outer border. Inner ramus a conical process, with a small apical seta.

Female. - Length $2.7 \mathrm{~mm}$. Gnathopod 1 very much similar to that of male, but inner margin of carpus more irregular. Gnathopod 2 different: inner prolongation of carpus triangular and apically pointed, rather than digitiform; inner border of propodus subequal to palmar border in length; palm with 2 prominent serrate elevations, a proximal and a distal, separated by a fairly deep concavity.

Remarks. - The 2nd male gnathopod is as figured by Chilton (1921, fig. 12). In K. H. Barnard's (1935) figure, the elongation of the carpal segment of this appendage is more pronounced and his specimens may represent the adult condition, or a dimorphic form. In all the 10 males in my collection, the 2 nd gnathopod is as illustrated here.

As observed by K. H. Barnard, the main character which distinguishes $\boldsymbol{P}$. digitata from $\boldsymbol{P}$. longicaudata (Bate \& Westwood, 1862) is the finger-like prolongation of the carpus of 2 nd male gnathopod of the former. In the specimens which Walker (1904) described as $P$. longicaudata, the carpus is produced, but the author has drawn this appendage in such a way that the merus overlaps the carpus, obscuring the latter partially. My specimens generally resemble those of Walker, and there is a possibility that $\boldsymbol{P}$. longicaudata Walker, 1904, is the same as $P$. digitata K. H. Barnard.

Genus Megamphopus Norman, 1869

Megamphopus sp. Fig. 6.

Material. - One male specimen was obtained by washing hydroids growing attached to bridge pilings at Thankasserry, Quilon, Kerala.

Male. - Length 2.9. mm. Body moderately stout, with diffused chromatophores; cephalon longer than 1st peraeon segment, non-rostrate; ocular lobes angularly produced; eyes large and occupying the entire area of the lobes. Peraeon segments subequal in length and moderately deep; first 3 segments of pleon subequal in length, 2nd deepest, lower margins convex, postero-inferior angles with a small rounded prominence, lower part of distal borders with a slight notch carrying a setule. Pleon segments 4 to 6 rather long, slender and successively becoming shorter, about as long as 2nd and 3rd segments of pleon combined, 


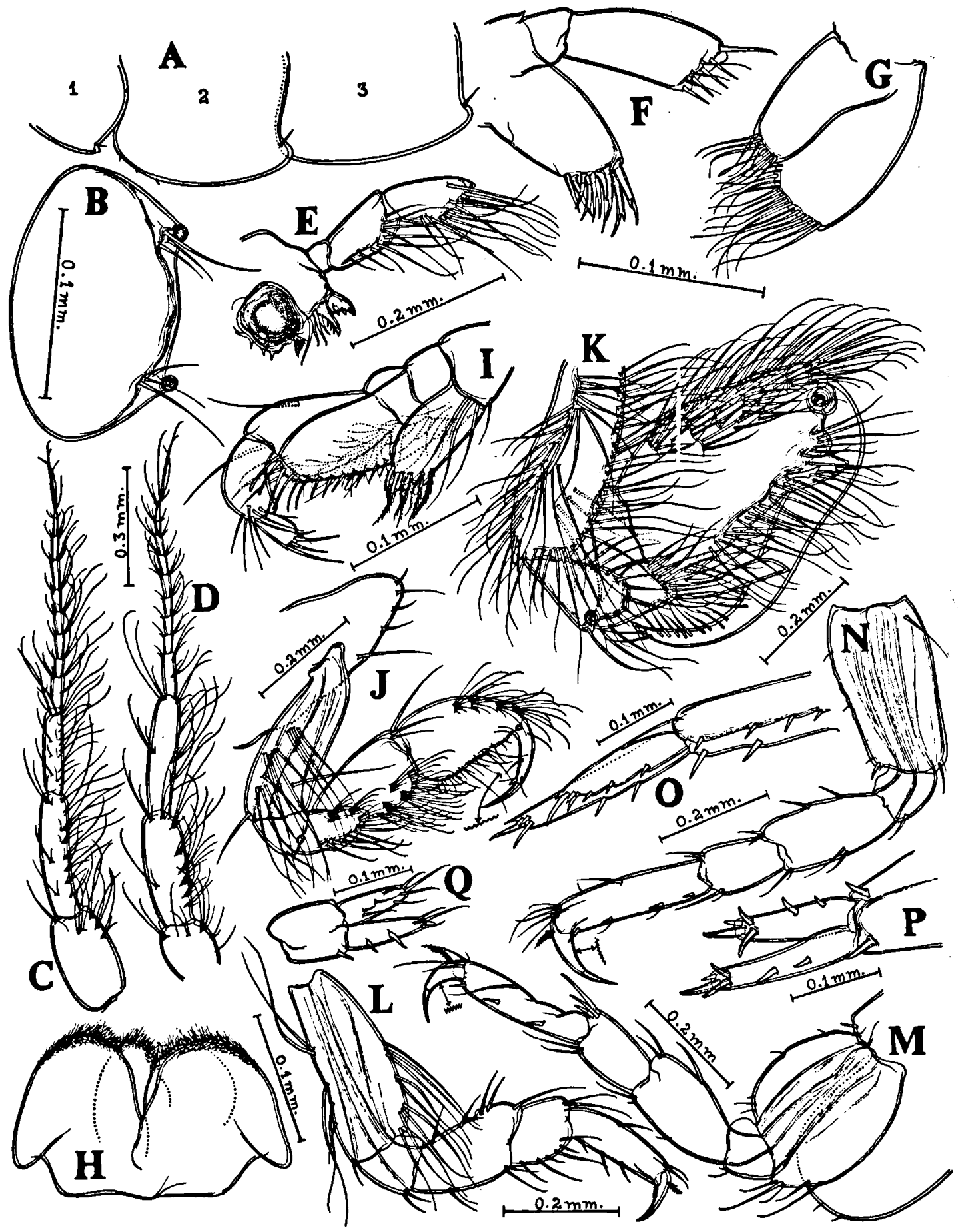

Fig. 6. Megamphopus sp., \&, $2.9 \mathrm{~mm}$. A, pleon epimera 1 to 3 (not drawn to scale); B, telson; $C$, antenna 1; D, antenna 2; E, mandible; F, maxilla 1; G, maxilla 2;
H, lower lip; I, maxilliped; J, gnathopod 1; K, gnathopod 2; $\mathrm{L}$, peraeopod 1; $\mathrm{M}$, peraeopod 3; $\mathrm{N}$, peraeopod 5; $O$, uropod $1 ; P$, uropod $2 ; Q$, uropod 3. 
4th $1 / 2$ as long as 3rd, 5th and 6th together as long as 4 th. Telson small, reaching the middle of the peduncle of 3rd uropod, broad and triangular, distal margin very slightly convex, with ear-like projecting lateral angles, having 3 or 4 submarginal setae at base. First coxal plate produced forwards and reaching the base of 3rd peduncular segment of 2nd antenna; 2nd coxa very much expanded and ovoid, rounded lower margin with a fringe of setules; 3rd, 4th, and the front lobe of 5th coxa subsimilar and rectangular, lower borders with a row of setae; hind lobe of 5th rounded and small; 6th coxa bilobed, lobes small and subsimilar; 7th coxal plate semicircular.

Antennae subsimilar and moderately setose. First segment of peduncle of antenna 1 twice as broad as 2 nd, but $1 / 3$ shorter; flagellum as long as last 2 peduncular segments combined, 9-segmented; accessory flagellum shorter than 1st flagellar segment and 2-segmented. Third peduncular segment of 2nd antenna almost rounded; 4th and 5th subequal in length, former much stouter; flagellum shorter than the combined length of last 2 segments of peduncle, 10-segmented.

Incisor process of mandible 4-dentate; lacinia mobilis an elongate blade-like structure, faintly denticulate; spine row consisting of 4 slender spines; molar well developed, but not strongly toothed. Palp 3-segmented; 1st segment very small; 2nd and 3rd subequal in length, former rectangular and with an inner row of setae, latter distally narrow and carrying a brush of long setae on inner margin. First maxilla without inner lobes; outer lobe broad, with 10 feebly barbed, distal spines; palp 2-segmented, 1st segment small, 2nd elongate-oblong, distally subtruncate and armed with 5 marginal spines and 3 submarginal setules. Second maxilla with smaller inner lobes, armed on distal margin with long setae. Inner lobes of lower lip small, but as tall as outer; outer lobes broad, sparsely hirsute on distal rounded border; mandibular processes short. Inner lobe of maxilliped oblong, subtruncate distal border carrying 3 flat spine-teeth and a few short plumose setae; outer lobe very tall, reaching distal margin of 2nd endopod segment, inner border very faintly crenulate and armed with a row of spines, gradually becoming seta-like on the rounded distal margin; 1st endopod segment small; 2nd much widened distally, closely fringed on the inner margin; 3rd segment more than $1 / 2$ length of 2 nd, strongly curved; 4 th segment $1 / 2$ as long as $3 \mathrm{rd}$, widening distally, with a long pointed nail mount- ed on the outer part of distal border, and with 3 small subsidiary ones below.

First gnathopod much smaller than 2nd; basis slightly shorter than next 3 segments combined, with 3 groups of long setae on inner surface; ischium small; merus a little less than $1 / 2$ length of basis, inner border with fascicles of setae; propodus suboval, longer than carpus, inner margin not defined from palm, palm oblique, irregular near finger hinge and setose; dactylus curved, with serrate inner margin and a long nail. Gnathopod 2 fully clothed with long setae, remotely resembling the corresponding appendage of Jassa falcata (Montagu, 1808); basis almost uniformly broad, inner surface and outer margin carrying long setae, distal part of outer bonder rounded; ischium triangular, inner border straight, unarmed, outer distally rounded, projecting and with a fringe of setae; merus suboval, subequal in length to ischium and partially overlapped by the latter proximally, slightly underriding carpus; carpus cup-shaped; propodus massive, rectangular, outer border slightly convex and with thick brushes of long setae, inner border with 2 prominent lobes - one at the proximal end and the other near the finger hinge - former thumb-like and much longer than latter, latter triangular, distally pointed and with a basal spine on inner surface, inner margin between the lobes straight and with a row of setae; palm transverse, very short, convex and with long setae; dactylus very long, distally curved, reaching merus, inner margin with a few slender setae. Peraeopods 1 and 2 subsimilar; basis of 1 st longer than next 2 segments combined, margins with long setae; ischium small, merus expanding distally, about $1 / 2$ as long as basis; carpus about as large as ischium, inner margin with a row of spine-setae; propodus slender, twice as long as carpus; dactylus not much curved, $1 / 2$ as long as propodus. Basis of 3 rd peraeopod much flattened, as long as next 2 segments combined; ischium and merus as in peraeopod 1, latter more than $1 / 2$ as long as basis; carpus rectangular, less than $1 / 2$ length of basis, outer apex with 3 spines; propodus slender, $1 / 5$ shorter than basis, with 3 submarginal spines on the inner side; dactylus curved, $1 / 2$ as long as propodus, inner margin serrate near base. Fourth and 5th peraeopods subsimilar, not much larger than 3rd; basis of 5th almost rectangular, as long as next 2 segments combined; remaining segments as in peraeopod 3 , but comparatively large and spiny.

Uropods 1 and 2 moderately spiny. Peduncle of 
1st longer than rami; with a strong distal spine; outer ramus $1 / 3$ shorter than inner. Uropod 2 smaller than 1st, distal spine of peduncle much smaller, outer ramus only $1 / 5$ shorter than inner: Uropod 3 small; peduncle as long as the subequal rami; rami with slender spines.

Remarks. - J. L. Barnard (1962) created Kermystheus and pointed out the differences between Eurystheus, Kermystheus, and Megamphopus. He also divided Megamphopus into 2 subgenera, Megamphopus and Segamphopus. According to the key and the short diagnosis published by him, the present specimens must certainly come under Megamphopus sensu stricto. But, in the general shape of the male 2nd gnathopod, this species shows very close resemblance to Kermystheus ociosa J. L. Barnard, 1962. In Kermystheus, the accessory flagellum is scale-like, but it is 2segmented in the present species. This raises the question whether the characters based on the number of segments of the accessory flagellum are valid or not. The accessory flagellum is an appendix which shows progressive degeneration, and in these Eurystheus-like genera, at any rate this character cannot be taken as a criterion for generic separation. J. L. Barnard, 1965: 539, suspected the artificiality of the arrangement made by him earlier, and even suggested that the new species $M$. abbotti J. L. Barnard, 1965, is apparently a Eurystheus that has lost one more flagellar article. If this be so, Kermystheus ociosa is a Megamphopus that has lost one more segment of the accessory flagellum. The separation of the isaeid genera is indeed very difficult.

The present species apparently belongs to Megamphopus and may most probably be $M$. longidactylus Chevreux, 1926. I could not consult the description of this species and hence refrain from giving it a name, or identifying it as $M$. longidactylus. I would have preferred to exclude this from the present communication, but for the fact that it is very interesting taxonomically.

Genus Eurystheus Spence Bate, 1856

Eurystheus afer (Stebbing, 1888). Figs. 7-8.

Gammaropsis afra Stebbing, 1888: 1097, pl. 113. 41.

Gammaropsis zeylanicus Walker, 1904: 282, pl. 6 fig.

Eurystheus afer Stebbing, 1906: 612; Pillai, 1957: 5556, fig. 13.

Material. - Twelve males and 15 females were collected from different habitats - mostly from among weeds
- along the coast of Manoli Island, Gulf of Mannar. Eight more specimens, 4 males and 4 females, were later obtained by washing hydroids growing on bridge pilings at Neendakara, Quilon, Kerala.

Male. - Length $3.7 \mathrm{~mm}$. Body slender, whitish, with faint brown chromatophores, cephalon as long as first 2 peraeon segments combined, very slightly rostrate; ocular lobes prominent, angularly produced, its apex not reaching the distal margin of the 3rd peduncular segment of 2nd antenna, with concave upper and convex lower margins; eyes large, flask-shaped (lageniform), lower portions occupying the entire space between the 2 converging lateral borders of the eye lobes and extending like a narrow neck on to the dorsal part of the cephalon on either side. Peraeon segments moderately deep, 1 st segment $1 / 3$ shorter than 2nd, following 4 segments subequal in length, 6th and 7 th a little longer. Pleon segments 1 to 3 gradually increasing in length, lower and distal borders convex, postero-inferior angles rounded, but with a shallow notch and a setule; segments 4 to 6 together only as long as 3rd, becoming shorter distally, 4th and 5th with a pair of subdistal stiff spine-setae dorso-laterally, 4th segment slightly depressed near origin. Telson small, a little broader than long, not reaching end of peduncle of 3 rd uropod, margins slightly convex, converging abruptly to a triangular apex carrying a plumose setule at each angle and a pair of blunt spines on the dorsal surface, each lateral margin with 1 or 2 plumose setules. Anterior 2 coxal plates more or less subsimilar, lower anterior corners rounded and very slightly produced; $3 \mathrm{rd}$ and 4th deeper, former obliquely truncate below; 5th prominently bilobed, front lobe rounded below and as deep as 4th, hind lobe small; 6th and 7th coxae ventrally a little emarginate and very shallow.

Antennae subequal in length; 1st peduncular segment of antenna 1 nearly 3 times as long as broad and $3 / 4$ the length of 2 nd segment, with an inner distal spine; 2 nd segment long and slender; 3 rd $1 / 2$ as long as 2 nd, but narrower; flagellum shorter than peduncle, 10-segmented; accessory flagellum 5-segmented and about as long as the first 4 segments of flagellum. Segments 1 and 2 of peduncle of 2 nd antenna small, 2 nd with a pointed gland cone reaching as far as the middle of 3rd segment; 3rd segment stout, $1 / 2$ as long as 4th; 4th and 5th subequal in length, former slightly stouter; flagellum 12-segmented, much shorter than peduncle. Both antennae moderately setose. 


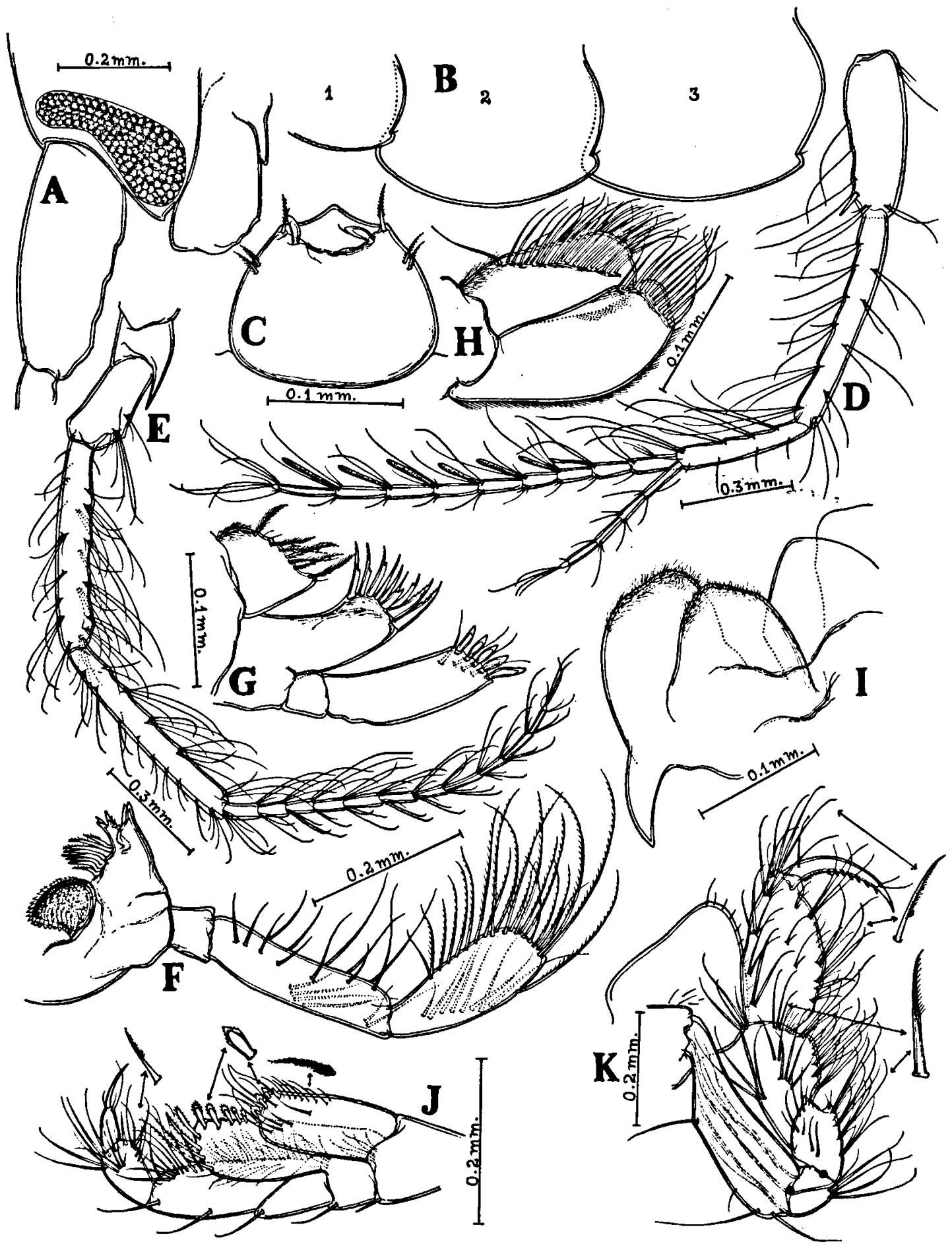

Fig. 7. Eurystheus afer (Stebbing, 1888), $\delta, 3.7 \mathrm{~mm}$. A, cephalon; B, pleon epimera 1 to 3 (not drawn to scale); C, telson; D, antenna 1; E, antenna 2; F, mand- ible; G, maxilla 1; H, maxilla 2; I, lower lip; J, maxilliped; K, gnathopod 1. 
Distal margin of upper lip evenly convex and hirsute. Incisor process of mandible feeble and tridentate; lacinia mobilis cut into pointed teeth, spines of the spine row slender, barbed and 8 in number; molar prominent, with dentate crown and a pectinate seta; palp stout, 1st segment very small, 2nd longest, inner margin sparsely setose, 3rd segment widening, fringed with long setae along inner and distal borders. Inner lobe of 1st maxilla triangular, apex narrowly produced into a rounded prominence bearing a setule, inner margin convex and with 7 plumose setae; outer lobe with 9 spine-teeth; 1st segment of palp short, 2nd long, slightly broader distally, apex armed with 5 marginal, flat spine-teeth and 4 submarginal setae. Second maxilla with shorter inner lobe, distally flattened, proximal half of inner border devoid of setae, but hirsute, outer lobe with the usual distal submarginal row of setae, outer margin hairy. Inner lobes of lower lip triangular, inner sloping borders hirsute; outer lobes broad and distally hirsute; mandibular processes not very long, decurrent and pointed. Inner lobe of maxilliped with 3 flat distal spine-teeth in addition to plumose spine-setae fringing its distal inner borders; outer lobe with 6 spine-teeth on inner margin, gradually becoming spine-setae along the sloping distal margin; 4th segment of endopod longer than $3 \mathrm{rd}$, its nail $1 / 2$ as long as the segment.

Gnathopod 1 very sm:lll; basis as long as next 3 segments combined, very narrow proximally and armed with a few long spine-setae on inner margin; ischium very short; merus twice the length of ischium, widely forked at distal end and moderately setose; carpus shorter than propodus, inner margin closely fringed with pectinate spine-setae; propodus nearly oval, broadest at the beginning of the palm, margins carrying numerous spine-setae; palm not defined, with setae and setules; dactylus reaching beyond palm, curved and pointed, inner border fringed with a row of denticles and setules. Gnathopod 2 very large; basis stout, narrow proximally, considerably longer than next 3 segments combined, outer margin as well as inner surface carrying long spine-setae; ischium very small, much broader than long; merus rectangular, distal border a little concave and armed submarginally with a circlet of spines; carpus very short, cup-shaped and as broad as propodus distally, inner margin very short, lobe-like and with a cluster of spine-setae; propodus massive, outer margin very nearly straight, with a submarginal row of fascicles of long setae, inner margin with bun- ches of marginal setae and ending distally in a small blunt prominence; palm oblique and highly irregular, defining spine prominent, followed by a deep semicircular depression, continued into a raised, irregularly flat-topped elevation, followed by a small depression and another small elevation near the hinge, the elevations carry stiff setae; dactylus stout, strongly arched, reaching the defining spine, inner border with a few spinules, middle part slightly bulging and with a spinetooth near the tip. Peraeopods 1 to 3 sparsely setose; 1st and 2nd subsimilar and shorter than the 3rd; basis as long as next 3 segments combined, inner margin fringed with rather long setae; ischium $1 / 3$ as long as merus; merus distally widening; carpus $1 / 3$ shorter than merus; propodus slender, as long as merus, narrowing a little distally; dactylus $1 / 2$ as long as propodus, slightly curved and pointed. Peraeopods 3 to 5 increasing in length; basis of 3rd nearly as long as broad, narrowing distally; ischium short; merus and carpus subequal in length, former a little wider distally and both carrying spines on apices; propodus slender, with a few spines on outer border; dactylus nearly straight. Peraeopods 4 and 5 subsimilar; basis longer than broad, with a few spines and spinules; merus $1 / 3$ shorter than basis, a little wider distally; carpus shorter than merus; propodus expanding distally, with a few spines and spinules along margins, outer apex with a cluster of long setae; dactylus curved and pointed, less than $1 / 2$ length of propodus.

Peduncle of 1st uropod longer than rami, with a long median spine distally and a row of marginal ones along upper border; outer ramus shorter than inner, both sparsely spinose along margins, but with a group of stouter ones along apices. Second uropod shorter than 1st; peduncle shorter than rami and poorly armed; outer ramus a little shorter than inner, both carrying a few spines along the upper margin and on apex. Third uropod shorter; peduncle a little longer than rami, reaching beyond peduncle of 2 nd uropod; outer ramus longer and broader, outer border carrying a spine and the apex with a group of spines; inner ramus slender.

Female. - Length $4.4 \mathrm{~mm}$. Very much like the male, but for the 2nd gnathopod. This appendage is much less massive and resembles closely the male 2nd gnathopod of $E$. atlanticus (Stebbing, 1888). Basis almost uniformly wide throughout and without the row of very long spine-setae on the 


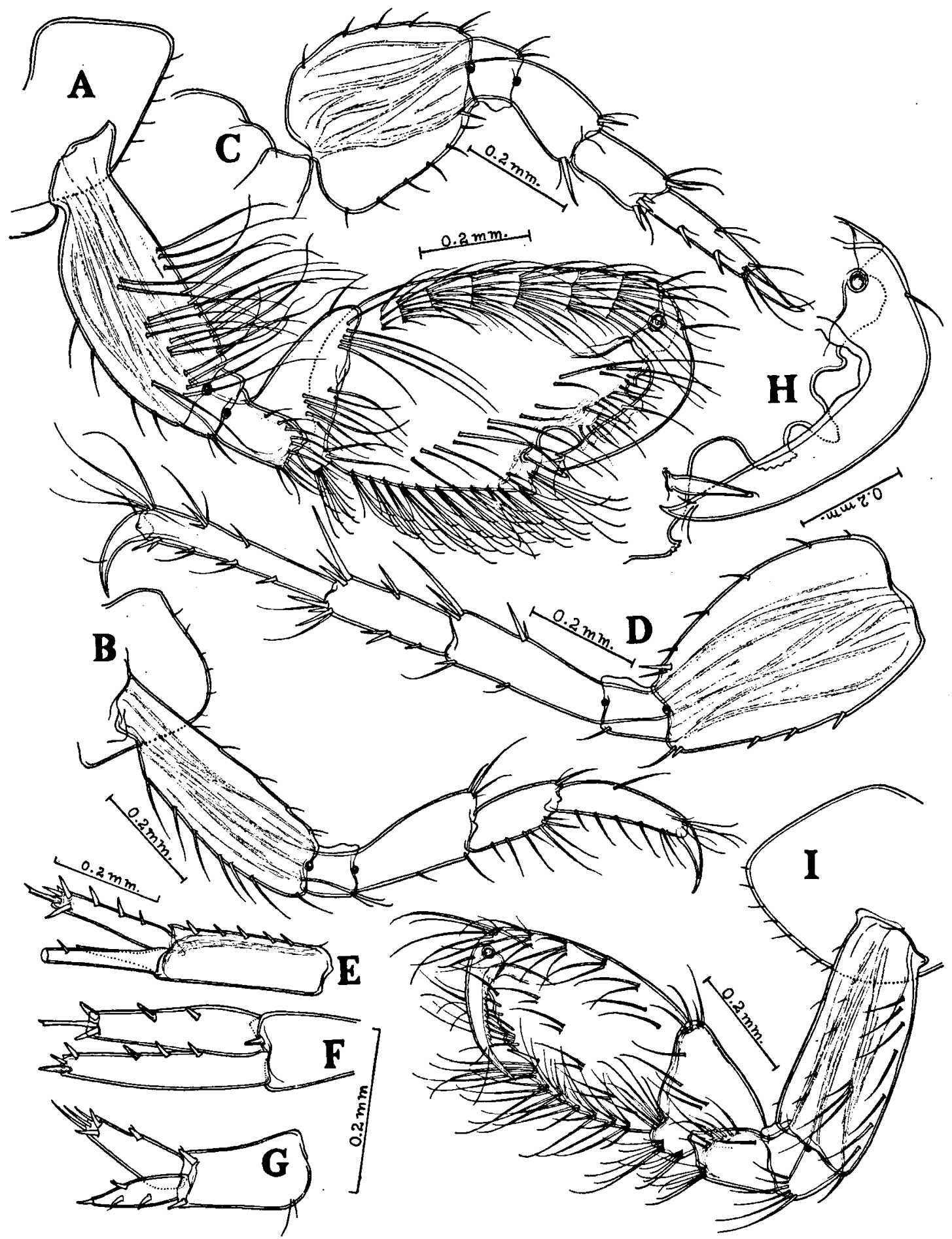

Fig. 8. Eurystheus afer (Stebbing, 1888). A-G, $\hat{\alpha}, 3.7$ mm: A, gnathopod 2; B, peraeopod 1; C, peraeopod 3; D, peraeopod 5; E, uropod 1; F, uropod 2; G, uropod 3.
$\mathrm{H}$, ô, $4.0 \mathrm{~mm}$ : gnathopod 2 (palm and dactylus).

I, $\%, 4.4 \mathrm{~mm}$ : gnathopod 2 . 
outer margin; merus distally produced; carpus longer than in male and triangular; propodus moderate in size, nearly of the same shape as in the male, but palm more even, without the deep concavities; dactylus more slender than in male and impinges on the distal tooth-like part of inner border of propodus, its inner margin with a row of short teeth.

Remarks. -- From the published descriptions of $E$. afer (Stebbing, 1888) and E. atlanticus (Stebbing, 1888), it is clear that the shape of the eye (the corneal part alone) shows a good deal of variation: lageniform, ovate or oblong (both vertically and horizontally). A lageniform eye can very well become vertically oblong if few of the top-most ocelli become indistinct after preservation. At any rate, the shape of the eye does not appear to be a trustworthy character. For example, the eye of $E$. atlanticus, shown by J. L. Barnard (1965), is quite different from Stebbing's original figure (1888, pl. 144). The shape of the palmar border of gnathopod 2 is also widely variable and its sculpturing changes with age (fig. $8 \mathrm{H}$ ). I therefore feel that the only reliable character which distinguishes $E$. afer from $E$. atlanticus, is the shape of the ocular lobe. In $E$. afer it is triangular, but cylindrical in $E$. atlanticus. This character should be taken as the basic criterion for the identification of these two species, irrespective of all other characters. If this view is accepted, it will be in agreement with Stebbing's original concept of these two species. However, it is to be pointed out that the above suggested morphological distinction between $E$. afer and $E$. atlanticus may appear useful only within the con-

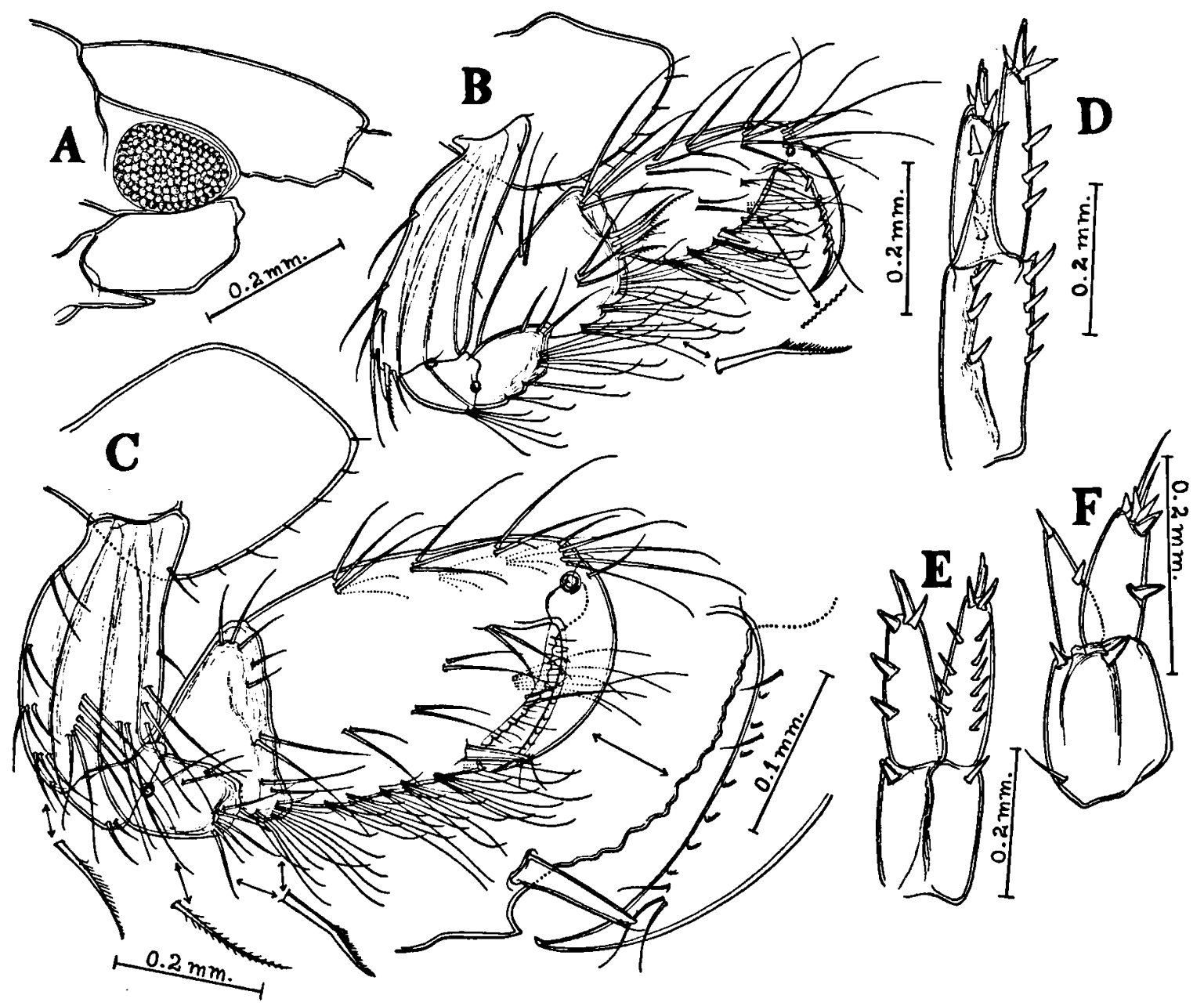

Fig. 9. Eurystheus atlanticus (Stebbing, 1888), of, $3.5 \mathrm{~mm}$. 1; E, uropod 2; F, uropod 3. A, cephalon; B, gnathopod 1; C, gnathopod 2; D, uropod 
fines of this specific locality and that they may differ from one another in entirely different ways in another situation. It will be useful if future workers studying populations of these two forms throughout the tropics in many localities, keep this fact in mind so that we may then find some common denominator deciding the identity of the two related forms.

In view of the fact that the shape of the ocular lobe is not clearly stated by many authors, I am not able to give complete synonymy. The synonymy drawn up above is based on the shape of the eye lobe.

\section{Eurystheus atlanticus (Stebbing, 1888). Fig. 9.}

Gammaropsis atlantica Stebbing, 1888: 1101, pl. 144. Eurystheus atlanticus Stebbing, 1906: 611; Pillai, 1957: 56-57, fig. 14; J. L. Barnard, 1965: 534-535, fig. 29.

Material. - A single male specimen obtained from Neendakara, Quilon, Kerala, by washing hydroids growing on bridge pilings.

Remarks. - This specimen (length $3.5 \mathrm{~mm}$ ) is identical to $E$. afer (Stebbing), except for the following differences:

The ocular lobes cylindrically produced and angularly rounded in front, the apex reaching the distal margin of the 3rd peduncular segment of 2nd antenna; eyes not large, round-oval and confined to the eye lobes. First gnathopod with a defining palmar spine. Second gnathopod not so large, resembling more closely the corresponding appendage of the female of $E$. afer, with a single, much shallower declivity near the inner angle, palmar border evenly cut into several small transluscent lobes, some rounded and others triangular; dactylus stout, but not so strongly arched, reaching beyond the palmar spine and with an evenly curved inner border. Longer inner ramus of 2 nd uropod carrying a row of spines along both margins. Peduncle of 3rd uropod subequal in length to the longer outer ramus; inner ramus without spines on inner margin.

Eurystheus digitatus Schellenberg, 1938.

Figs. $10-11$.

Eurystheus digitatus Schellenberg, 1938: 84-86, fig. 44; J. L. Barnard, 1965: 535-536, fig. 30 .

Material. - 4 males and 9 females collected from' among algae growing attached to submerged stones in the littoral area at Mandapam.

Male. - Length $3.5 \mathrm{~mm}$. Body slender, irregularly and sparsely pigmented; cephalon subequal in length to first 2 peraeon segments combined, nonrostrate, with a crown of dark pigment spots dorso-laterally close to the anterior border; ocular lobes large and projecting as far as the middle of the 3rd peduncular segment of 2 nd antenna, anteriorly subangular; eyes large, occupying almost the entire area of the eye lobes, with dark reddish central and lighter peripheral regions. Peraeon smooth, segments nearly subequal in length and depth; pleon segments 1 to 3 gradually increasing in length, 1st very shallow, 2nd and 3rd nearly subequal in depth, lower margins slightly convex, postero-inferior angles forming small tooth-like points, the much convex distal borders projecting beyond these points; 4th pleon segment as long as 5th and 6th combined, deeper than 5th; 4th and 5th with a pair of subdistal, stiff spine-setae dorso-laterally; 6th segment small and almost squarish. Telson a little broader than long at base, dorsal surface slightly folded, lateral borders very nearly straight, each with 1 or 2 setules laterally, and with a distal spine having a plumose setule at its base. First coxal plate not very deep, directed slightly forwards; 2nd and 3rd subsimilar, deeper than 1st, nearly squarish, lower borders straight; 4th deeper and almost rounded; 5 th and 6th bilobed, front lobes deeper than hind ones; 7th nearly oval and very small.

Segments 1 and 3 of peduncle of antenna 1 subequal in length, former more than twice as broad as latter; 2nd segment as broad as 3rd, but longer; flagellum less than the combined length of last 2 peduncular segments and 8-segmented; accessory flagellum 4-segmented and nearly as long as first 3 flagellar segments combined. Second antenna as long as 1st; segments 1 to 3 of peduncle subequal in length; flagellum 7-segmented, shorter than the combined length of last 2 peduncular segments.

Incisor process of mandible well formed; lacinia mobilis small and distally cut into sharp teeth, spine row consisting of 5 barbed spines; molar well formed and finely dentate, with a long, slender seta; palp stout and exactly like that of other species of the genus. First maxilla with a small conical inner lobe carrying 3 spine-setae on the inner distal part, apex with 2 very short spinules; outer lobe with 11 barbed spines; palp armed with 6 distal spine-teeth and 5 sub-marginal setules. Inner lobe of 2 nd maxilla shorter and narrower than outer, inner border with a row of submarginal spine-setae, obliquely passing towards 


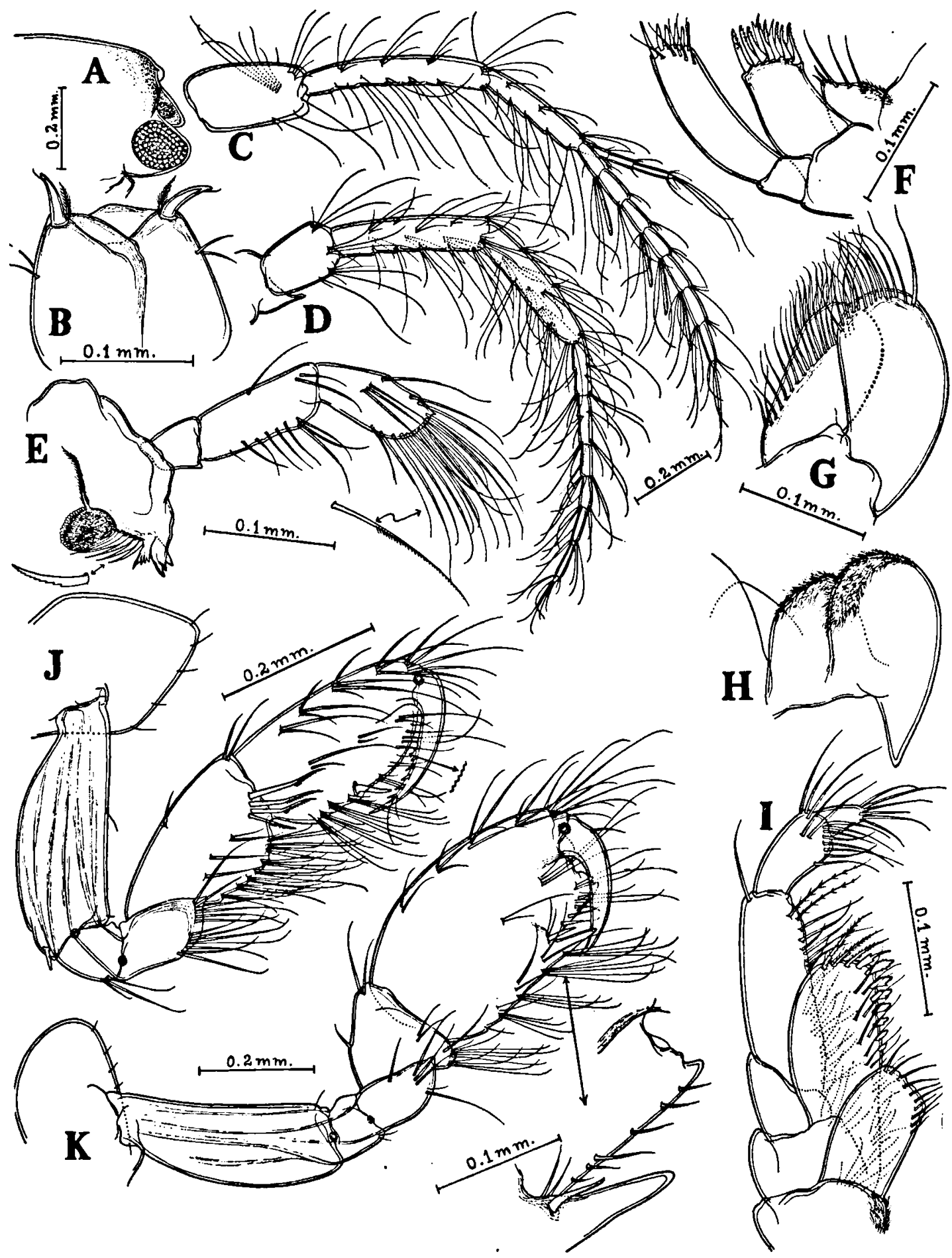

Fig. 10. Eurystheus digitatus Schellenberg, 1938, ô, $3.5 \quad$ E, mandible; F, maxilla 1; G, maxilla 2; H, lower lip; mm. A, cephalon; B, telson; C, antenna 1; D, antenna 2; I, maxilliped; J, gnathopod 1; K, gnathopod 2. 
outer apex; outer lobe curving over inner, rounded distal border of both lobes armed with setae. Lobes of lower lip distally hirsute, inner obliquely truncate and outer rounded; mandibular processes nearly pointed and slightly decurrent. Inner lobe of maxilliped oblong, reaching the distal margin of 1st endopod segment, armed with small setae only; outer lobe extending to middle of 2 nd endopod segment, inner margin armed with 7 flat, barbed spine-teeth, distal border carrying 4 spinesetae; endopod 4-segmented; dactylus missing.

Gnathopod 1 small; basis widening distally, less than the combined length of next 3 segments and poorly armed; ischium short, $1 / 2$ length of merus; merus distally produced, pointed and armed with setae; carpus nearly triangular, subequal to propodus in length, inner margin closely fringed with long spine-setae; propodus oval, outer border nearly straight, inner convex, both armed with fascicles of spine-setae; palm not clearly marked out from inner margin, but with a stout defining spine, minutely crenulate; dactylus pointed, curved and reaching beyond the defining spine, inner border with a few spines. Second gnathopod much larger than 1st; 2nd, 3rd and 4th segments subsimilar to corresponding ones of 1 st gnathopod; carpus triangular, inner border very short and lobe-like, carrying a tuft of spine-setae; propodus massive, inner margin distally produced into a pointed process, having a stout spine and 1 or 2 small setules at inner base; palm very short, produced into a prominent projection near the hinge and abruptly sloping down to the base of the defining spine; dactylus curved, reaching the base of the thumb-like process of propodus, inner border with a row of small denticles. Peraeopods 1 and 2 alike; basis sparsely spiny; merus and carpus subequal in length, former widening dis-

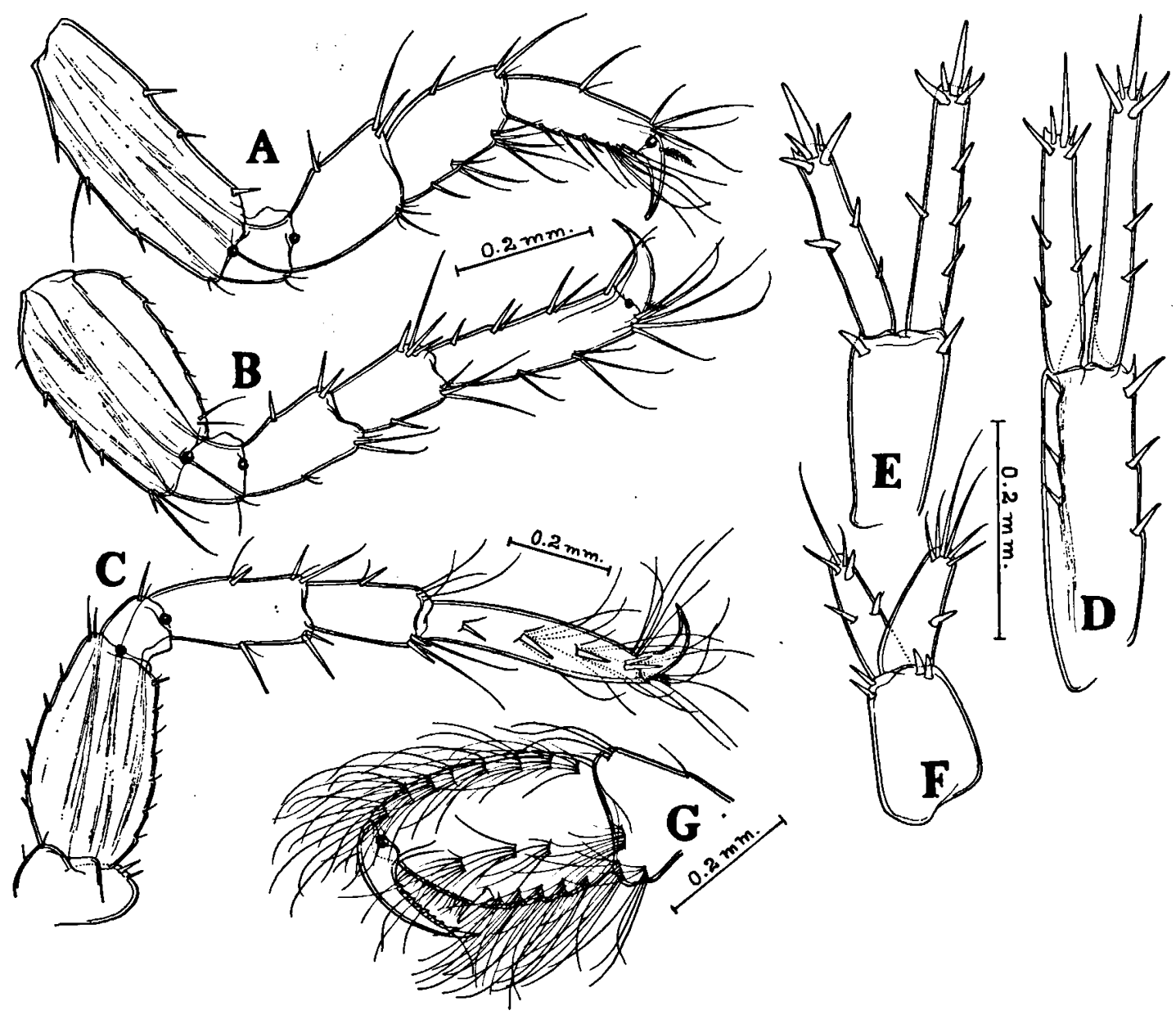

Fig. 11. Eurystheus digitatus Schellenberg, 1938. A-F, ô, $3.5 \mathrm{~mm}$ : A, peraeopod 1; B, peraeopod 3; C, peraeo- pod 4; D, uropod 1; E, uropod 2; F, uropod 3 . G.,$+ 3.7 \mathrm{~mm}$ : gnathopod 2 (segments 5 to 7). 
tally; propodus slender, $1 / 6$ longer than carpus, margins armed, inner more closely than outer; dactylus gently curved, about $1 / 2$ length of propodus. Peraeopods 3 to 5 increasing in length, subsimilar and more spiny than the preceding ones; basis somewhat flattened, oblong-oval, distally narrow; ischium small, merus longer than carpus, slightly expanding distally; propodus slender, subequal in length to merus and carpus combined, distally carrying very long spine-setae; dactylus pointed and curved.

Uropods 1 and 2 extending almost equally far back. Peduncle of 1st longer than the longer inner ramus, distal border with a broad median spine, rami apically truncate and with a cluster of unequal spines. Second uropod much shorter than 1st, peduncle subequal in length to the shorter outer ramus, distal border without the median spine, rami as in 1st uropod. Third uropod small, peduncle as long as the subequal rami, each apically beset with a cluster of spines.

Female. - Length $3.7 \mathrm{~mm}$. In general shape resembling the male except in the more setose 2nd gnathopods. Proximal 4 segments of this appendage subsimilar to corresponding ones in the male, but propodus much less massive, longer than broad, widening out from base, the greatest breadth at the origin of palm, margins heavily setose. Palm not very convex, but oblique, with a defining spine. Dactylus strong, curved and reaching beyond the defining spine, its inner border carrying a row of small spines.

The crown of pigment spots encircling the cephalon more pronounced than in the male.

Remarks. - This species like $E$. setiferus Schellenberg, 1938, is very conspicuously setose. The males in my collection appear to be sub-adults, and the figure of the 2nd gnathopod that $I$ have given agrees in overall proportion with Schellenberg's (1938) fig. 44F of a juvenile male. (Schellenberg's figure lacks the setal spine in the crotch of the thumb). My specimens also show close similarity to the male figured by J. L. Barnard (1965), except in the structure of the 2nd gnathopod. In Barnard's illustration, the proximal inner part of propodus is produced into a strong, characteristic process and there is a smaller process near the hinge with the dactylus. In contrast, my specimens have the proximal process situated in the middle of the inner border and the distal process is rather broad and flat. Barnard's study how- ever shows that $E$. digitatus exhibits considerable intraspecific variation.

The presence of dark spots on the cephalic somite is said to be characteristic of $E$. digitatus, though complete reliance cannot be made on them (J. L. Barnard, 1965).

Eurystheus anomalus sp. n. Figs. 12-13.

Material. - 5 males were collected from among algae and weeds growing on a buoy in the Pamban area, Gulf of Mannar.

Male. - Length $4.4 \mathrm{~mm}$. Body rather robust, irregularly pigmented; cephalon as long as first 2 peraeon segments combined, non-rostrate; ocular lobes projecting to a third of the length of 1st peduncular segment of antenna 1, subangular; eyes large, oval, with dark central and lighter peripheral portions. Peraeon segments smooth, subequal in length and moderately deep. Anterior 2 segments of pleon subequal in length; 3rd slightly longer, all with a dorso-distal setule, depth gradually increasing, inferior margins convex, postero-lateral corners of pleon segments 1 and 2 tooth-like, that of 3 rd slightly produced and rounded, margin above much convex. Pleon segments 4 to 6 distinct; 4 th and 5th subequal in length and depth, each with a pair of stiff, dorsolateral spine-seta near distal end; 6th segment shallower and shorter. Telson apically cleft, each half with an apical spine and 2 lateral plumose setae. Coxal plates shallow; 1st directed forwards, with parallel margins; 2nd slightly emarginate ventrally and fringed with a few slender setae at the anterior corner; 3rd, 4th, and 5th subsimilar and nearly as broad as deep, ventral margins convex; 6th faintly bilobed; 7th nearly oval.

First antenna longer than 2nd; 1st segment of peduncle stout, $1 / 4$ shorter than 2 nd; 3 rd segment slender and subequal in length to 1st; flagellum 11-segmented and shorter than peduncle; accessory flagellum 6-segmented, reaching the 4th flagellar segment. Proximal 3 segments of the peduncle of 2 nd antenna short and stout, gland cone produced and pointed: 4th and 5th segments subsimilar and elongated; flagellum nearly $1 / 5$ longer than the ultimate peduncular segment, stout and 9-segmented. Both antennae rather prominently hirsute.

Upper lip broad, distally a little emarginate and strongly hairy. Incisor process of mandible well chitinised and strongly dentate; lacinia mobilis small and well toothed, spine row consisting of 7 slender, denticulated spines and a few plumose 

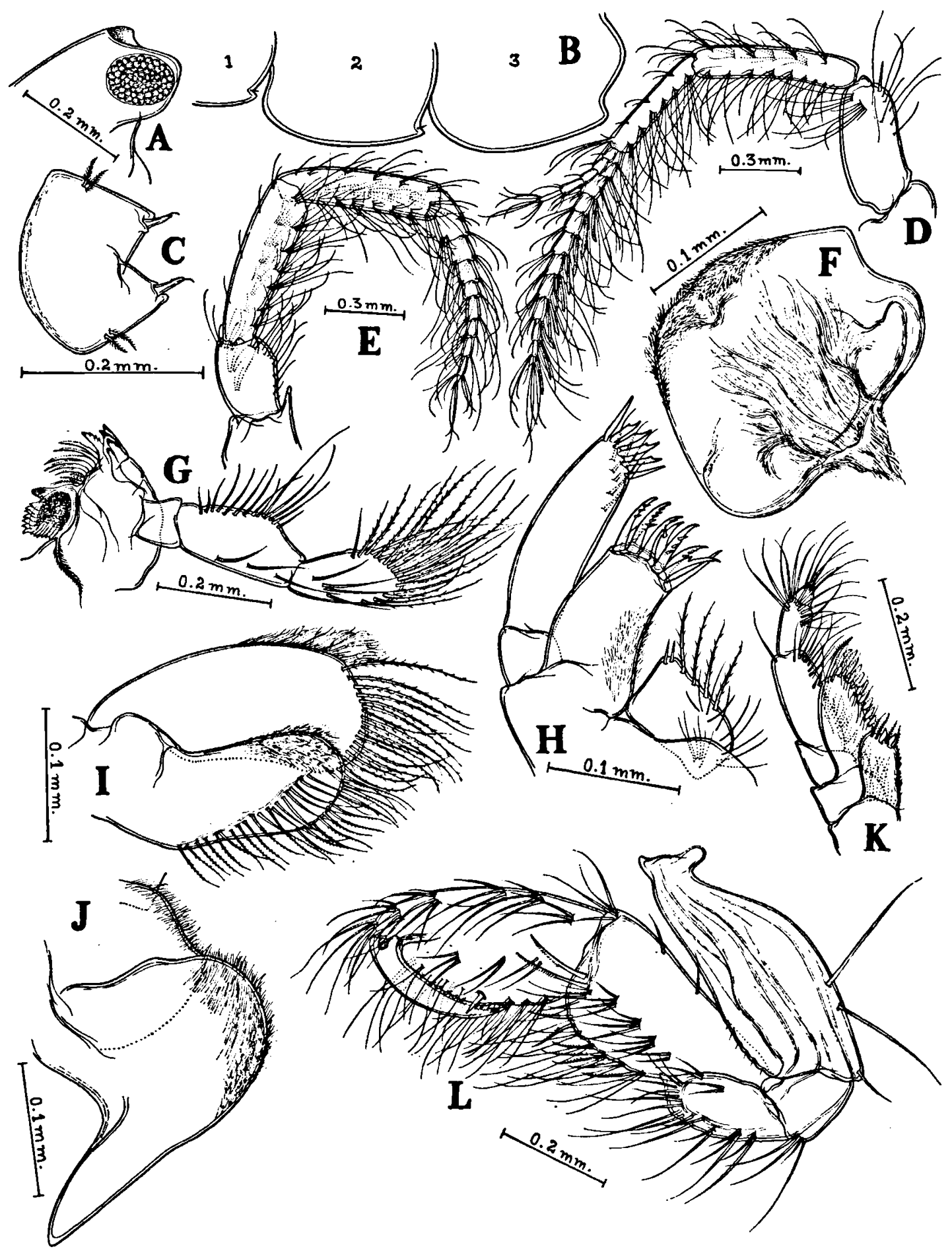

Fig. 12. Eurystheus anomalus sp. n., ô, $4.4 \mathrm{~mm}$. A, cephalon; B, pleon epimera 1 to 3 (not drawn to scale); C, telson; D, antenna 1; E, antenna 2; F, upper lip; G, mandible; H, maxilla 1; I, maxilla 2; J, lower lip; K, maxilliped; $\mathbf{L}$, gnathopod 1 . 
setae; molar well formed, dentate and with a plumose seta; palp very much as in other species of Eurystheus, but 2 nd segment abruptly constricted at the distal third of inner margin; segments 2 and 3 prominently setose. Inner lobe of 1 st maxilla conical, apex carrying 2 short spines and inner border a row of setae; inner border of outer lobe hairy and its distal end armed with 9 denticulated spine-teeth; distal segment of palp with 6 marginal spine-teeth and 5 submarginal setae. Second maxilla very much as in other species of Eurystheus. Inner lobes of lower lip with hirsute distal margins; outer lobe broad, distally rounded and hairy; mandibular processes long and nearly pointed. Inner lobe of maxilliped reaching slightly beyond 1st endopod segment, apex carrying 2 short, flat spines and a row of small setae; outer lobe reaching beyond middle of 2 nd endopod segment, broadly oval, armed with 12 flat, pectinate spines; palp rather small and 4-segmented, 3rd segment with a conspicuous distal cluster of setae, 4th segment conical.

Gnathopod 1 small; basis proximally very narrow, outer distal margin faintly crenate; ischium short and squarish; merus oblong-oval, longer than ischium, distally pointed and with a submarginal circlet of spine-setae; carpus subequal in length to propodus, distally broader than propodus, inner margin fringed with fascicles of pectinate and simple spine-setae; propodus oval, strongly setose; palm almost continuous with inner border, but with defining spine; dactylus curved and reaching beyond the defining spine, its inner border armed with a row of denticles. Gnathopod 2 large, chelate and strongly setose; basis proximally very narrow; merus nearly oval, longer than ischium, rounded distal part with a submarginal circlet of setae; carpus triangular, inner border very short; propodus very massive, both margins heavily setose, inner distally produced into a blunt, triangular lobe with a sloping inner margin; palm very short; dactylus strong, overlapping and reaching the lobe of propodus, with a concavity followed by a prominent bulge near the finger hinge, inner border dentate. Peraeopods 1 and 2 stout and sparsely setose; basis widening distally; ischium $1 / 4$ shorter than merus; merus distally expanding; carpus subequal in length to merus, margins convex; propodus slender narrowing distally, longer than carpus; dactylus $1 / 2$ as long as propodus, slightly curved and pointed. Peraeopod 3 larger; basis somewhat broad; ischium small; merus and carpus nearly oblong, former longer and distally expand- ing a little; propodus as long as merus and carpus combined, widest at hinge, outer margin with fascicles of long setae, inner with a few long spines and slender setae; dactylus upcurved, pointed and less than $1 / 2$ length of propodus. Peraeopods 4 and 5 missing in all specimens.

Uropods 1 to 3 extending equally far back. First longer than 2 nd, peduncle subequal to the longer inner ramus, moderately spiny along margins and with a very stout lower distal spine, rami distally truncate; outer about $1 / 3$ shorter than inner, both moderately spiny and feebly serrate along the upper margins and with a cluster of long spines on apex. Peduncle of 2nd uropod as long as the shorter outer ramus, with a short, stout median spine on distal border; outer ramus $1 / 3$ shorter than inner, both distally truncate and moderately spiny. Third uropod with a broadly oval peduncle, longer than the subequal rami, armed with a group of spines on apices.

Remarks. - In general appearance these specimens show close resemblance to species of Eurystheus as is particularly evident in the shape of the 3rd uropod and telson, and in the palp of the mandible. However, the 6-segmented accessory flagellum of 1st antenna, and the comparatively short and stout flagellum of the 2 nd antenna, are quite unlike those of any other known species of Eurystheus. The gnathopods are also extremely setose and the peraeopods show a superficial resemblance to those of species of Ampithoe Leach, 1813.

The structure of the 2nd gnathopod and the stoutness of the 2nd antennal flagellum seems to indicate that this species is a typical member of the genus Adulla Chevreux, 1901. But, as J. L. Barnard (1965: 533) pointed out, there are a number of species of Eurystheus possessing a 2nd gnathopod approaching the transverse palm and even the semichelate condition of Adulla. Hence, the stoutness of the 2nd antennal flagellum, which is a minor quantitative feature, of doubtful generic value, alone remains as a distinction between the two related genera. If otherwise, the present species is a true Adulla; but for the present, following Barnard, I am describing it under Eurystheus.

In shape, the 6th and 7th segments of the male 2 nd gnathopod of $E$. anomalus sp. n. show close similarity to $E$. lina Kunkel, 1910, but are much more stout. Obviously, Adulla chelifer Chevreux, 1901, Eurystheus semichelatus K. H. 


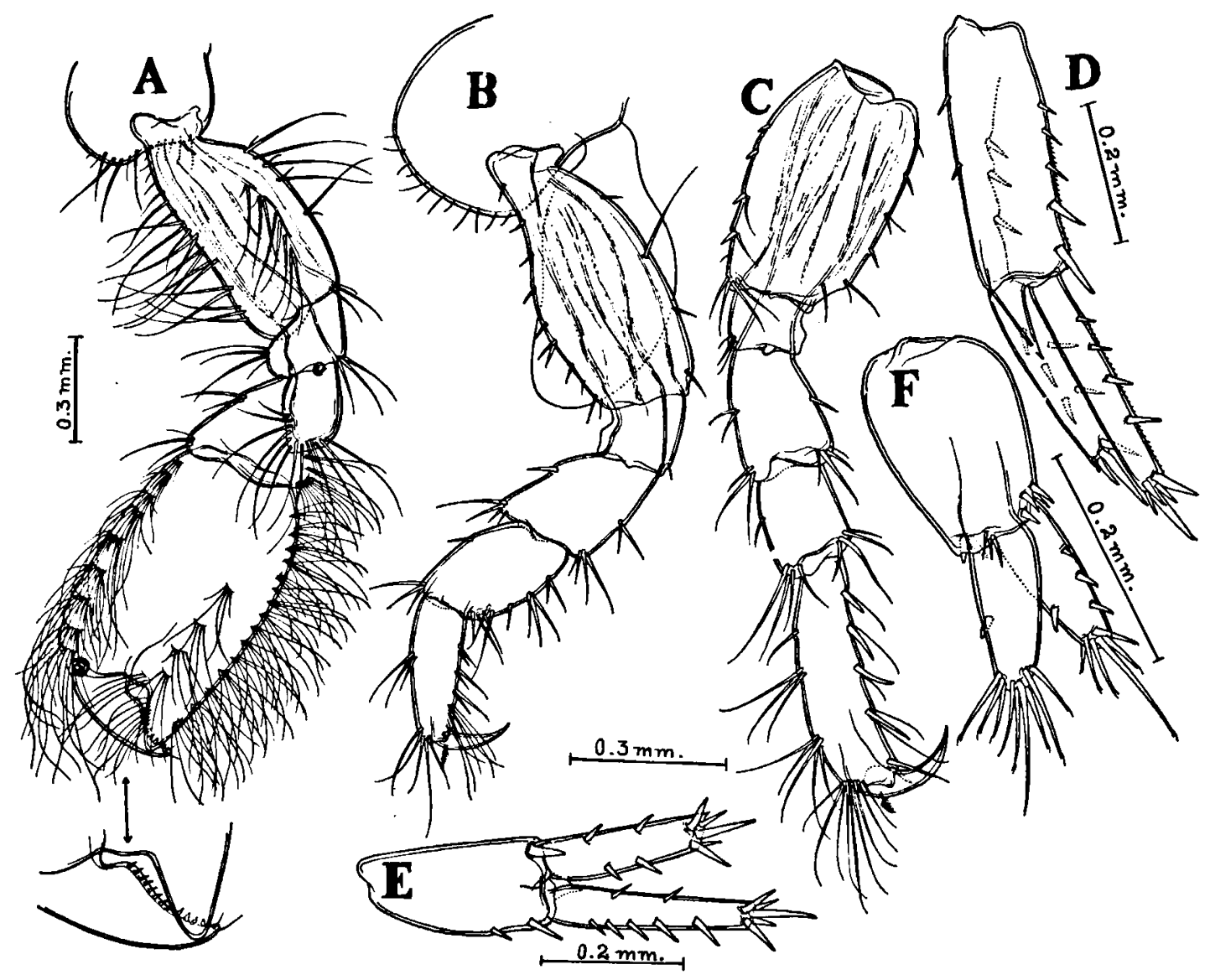

Fig. 13. Eurystheus anomalus sp. n., đ, 4.4. mm. A, gnathopod 2; B, peraeopod 1; C, peraeopod 3; D, uropod

Barnard, 1957, Eurystheus lina Kunkel, 1910, and the present species are very close and may perhaps form a subgenus under Eurystheus.

Genus Cheiriphotis Walker, 1904

Cheiriphotis megacheles (Giles, 1885). Fig. 14.

Melita megacheles Giles, 1885: 70, pl. 3.

Eurystheus hirsutus Giles, 1887: 227, pl. 8; Stebbing, 1906: 615.

Cheiriphotis megacheles Walker, 1904: 284, pl. 6 fig. 42; Stebbing, 1910: 461; Pirlot, 1938: 345; K. H. Barnard, 1937: 167-168, fig. 14; K. H. Barnard, 1940: 480; Pillai, 1957: 57-58, fig. 15; Nayar, 1959: 33, pl. 11 figs. 23-25; J. L. Barnard, 1962: 17, fig. 4. 249.

Cheiriphotis durbanensis K. H. Barnard, 1916: 247-

Cheiriphotis delloyei Pirlot, 1934: 231-235, fig. 100.

Material. -4 males and 2 females were obtained from the inshore plankton collected at Thankasserry, Quilon. Kerala.

Male. - Length $7.1 \mathrm{~mm}$. Body slender and conspicuously pigmented; cephalon subequal in length to anterior 2 peraeon segments combined, non-
1; E, uropod 2; F, uropod 3.

rostrate; ocular lobes moderately produced and angular; eyes round-oval and reddish-brown. Peraeon segments successively becoming longer, the last 3 subequal in length. Anterior 2 pleon segments subsimilar; 3rd longer, lower margins in all convex, distal borders of segments 1 and 2 bulging and armed with a few setules in the lower part, postero-lateral angle of 3rd somewhat upturned, carrying a small tooth and a setule, hind border bulging; segments 4 to 6 together about as long as 3rd; 4 th nearly $1 / 2$ its length; 5 th shortest, together with 6 th subequal in length to 4 th. Telson roughly rectangular, broader than long, with a slight distal median projection, lateral angles with a bunch of setae. Coxae small; 1st anteriorly produced, fringed with long setae; 2nd subrectangular, lower margin setose; 3rd and 4th subsimilar, round-oval; 5th and 6th faintly bilobed, former deeper; 7th coxa very small, nearly rectangular, front and hind margins armed with a row of setules. 


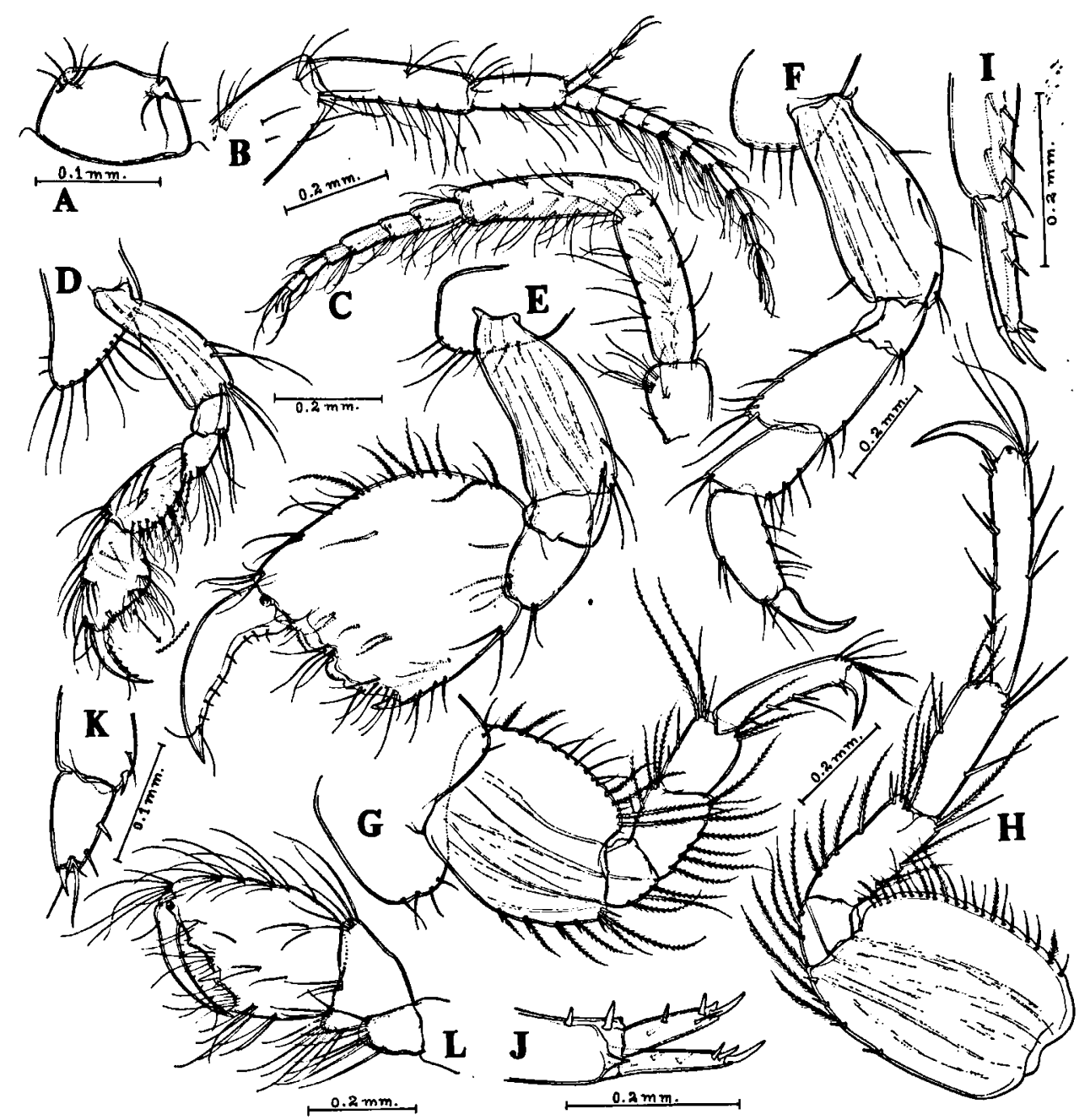

Fig. 14. Cheiriphotis megacheles (Giles, 1885). A-K, $\hat{\delta}$, $7.1 \mathrm{~mm}$ : A, telson; $B$, antenna 1; C, antenna 2; D, gnathopod 1; E, gnathopod 2; $F$, peraeopod 1; G, perae-

Antennae subsimilar and moderately setose. Segment 1 of peduncle of 1st antenna subequal in length to 2nd segment, but wider; 3rd more than $1 / 2$ the length of 2 nd; flagellum nearly as long as the last 2 peduncular segments combined and 10segmented; accessory flagellum 3-segmented and as long as first 2 flagellar segments combined. Ultimate and penultimate segments of peduncle of 2nd antenna subsimilar; flagellum longer than last peduncular segment and 6-segmented, last segment ending in 2 claw-like spines.

Mouth parts normal. Number of setae on inner lobe of 1st maxilla variable.

First gnathopod small; basis nearly as long as next 3 segments combined; ischium squarish, opod 3; H, peraeopod 5; I, uropod 1; J, uropod 2; K uropod 3.

L, \&, $3.5 \mathrm{~mm}$ : gnathopod 2 .

shorter than merus; merus triangular, carpus oblong-oval, $2 / 3$ the length of basis, inner margin very setose; propodus subequal to carpus in length, abruptly widening towards the palm, inner margin merging into the oblique, minutely serrate palm; palm ill-defined, moderately setose and with 2 spines, one proximal and the other distal; dactylus $2 / 3$ length of propodus, curved inner margin serrate and with a row of small spines. Second gnathopod very much longer than 1st; basis short, nearly as long as inner margin of propodus and poorly armed; ischium transversely rectangular; merus about $1 / 2$ as long as basis and somewhat oblong; carpus completely fused with the massive propodus; propodus subquadrate, longer than 
wide, outer margin $1 / 3$ longer than inner, uniformly convex and fringed with a row of plumose setae, inner border nearly straight, ending in a sharp, spine-like tooth; palm sub-transverse and irregular, sparsely setose, sinuous in the middle and with 3 broad, flattened tooth-like projections; dactylus stout and curved, as long as palm, inner margin irregular, a little sinuous near base and with a row of spinules. Peraeopods 1 and 2 subsimilar, 1st larger; basis as in 2nd gnathopod. broader distally and shorter than next 3 segments combined; merus more than $1 / 2$ length of basis, outer distal part projecting and armed with a row of pectinate setae; carpus about $1 / 4$ shorter than merus; propodus oblong, $1 / 2$ length of basis, narrowing distally; dactylus $2 / 3$ as long as propodus, curved and unarmed. Peraeopods 3 to 5 progressively increasing in length; basis highly expanded, in 3rd about as long as broad, both borders with long setae; carpus rectangular, subequal to merus in length; propodus shorter than basis, inner border with a few spines and outer with an apical cluster of setae; dactylus upcurved and about $1 / 2$ length of propodus. Peraeopods 4 and 5 subsimilar, armed like 3rd; 5th extending beyond uropods, basis longer than broad and longer than next 2 segments combined, merus and carpus subsimilar and rectangular, propodus longer than basis, dactylus as in 3 rd peraeopod and less than $1 / 2$ length of propodus.

Uropods 1 and 2 subsimilar; 1st larger, peduncle and rami subequal in length and spiny. Peduncle of 2 nd uropod with a tooth-like prominence on distal margin, rami subequal in length and shorter than peduncle. Third uropod uniramous, peduncle longer than ramus, distal part of inner border with a stiff spine, inner margin of ramus with 2 spines, apex with 1 spine and a few seta.

Female. - Length $3.5 \mathrm{~mm}$. Gnathopod 2 much smaller and more setose; carpus well formed and triangular, inner margin setose, short and lobelike; propodus subovate, outer border twice length of inner, latter ending in a small distal tooth; palm oblique, with 2 triangular elevations, the proximal one carrying a strong spine; dactylus more slender than in male and overreaching distal tooth on inner border.

Remarks. - K. H. Barnard (1937) discussed at length the synonymy of this species and commented on the variations of gnathopod 2. My specimens have the propodus of gnathopod 2 exactly similar to those illustrated by Walker (1904) and Pillai (1957). The figures of the male gnathopod given by K. H. Barnard (1937), Pirlot (1938), and J. L. Barnard (1962) are different mainly in the fact that the inner border of the propodus is shorter and the palm rather oblique, more so in Pirlot's and J. L. Barnard's specimens. In fully adult males, the inner border of the propodus is rather long and the palm nearly transverse. But in view of the finding that $C$. megacheles is polymorphic, these variations are not of any significance. My specimens are very much like the type.

As observed by J. L. Barnard (1962), the presence or absence of an inner ramus in uropod 3 has now assumed some importance. Walker has described a spiniferous tubercle as representing the inner ramus; K. H. Barnard has shown a spine, but makes no mention of the ramus. J. L. Barnard has illustrated a distinctly biramous 3rd uropod. My specimens show a distal inner spine on the peduncle of the 3rd uropod, which hardly seems to represent the reduced inner ramus. However, J. L. Barnard's observation that Cheiriphotis adults often loose one ramus of uropod 3, seems to be correct since my specimens, like those of Pillai, are above $7 \mathrm{~mm}$, while those of Walker, K. H. Barnard and J. L. Barnard are only about half the size of the present specimens.

\section{ACKNOWLEDGEMENTS}

The writer wishes to express his gratitude to Dr. N. Krishna Pillai, Reader in Marine Biology, University of Kerala, for suggesting this problem, for his guidance and encouragement throughout its development. The author also records his grateful appreciation to Dr. J. L. Barnard, Curator of Crustacea, Smithsonian Institution, Washington, for his sustained help and interest in this investigation. The assistance rendered by Mr. P. V. Ramachandran Nair of the Central Marine Fisheries at Mandapam, and Mr. K. R. Purushothaman Nair of the S.N. College Marine Station at Quilon, during my collection tours, is warmly appreciated.

This study was performed during the tenancy of a Government of India research scholarship. I thank the Government for the award and the University of Kerala for providing space and equipment.

Finally, my thanks go especially to Professor J. H. Stock of the Institute of Taxonomic Zoology, University of Amsterdam, for helping me in the publication of this paper. 


\section{REFERENCES}

Barnard, J. L., 1958. Index to the families, genera and species of the gammaridean Amphipoda (Crustacea). Occ. Pap. Allan Hancosk Found., 19: 1-145.

-, 1962. Benthic marine Amphipoda of southern California. Families Aoridae, Photidae, Ischyroceridae, Corophiidae, Podoceridae. Pacific Natural., 3 (1): 3-72.

-, 1963. Los Anfipodos bentonicos marinos de la costa occidental de Baja, California. Revista Soc. Mexicana Hist. nat., $24205-273$.

-, 1964. Revision of some families, genera and species of gammaridean Amphipoda. Crustaceana, 7 (1): 49-74.

-, 1965. Marine Amphipoda of atolls in Micronesia. Proc. U.S. nation. Mus., 117 : 459-552.

Barnard, K. H., 1916. Contributions to the crustacean fauna of South Africa, 5. Amphipoda. Ann. S. Afr. Mus., 15 (3) : 105-302.

-, 1925. Contributions to the crustacean fauna of South Africa, 8. Further additions to the list of Amphipoda. Ann. S. Afr. Mus., $20: 319-380$.

-, 1935. Report on some Amphipoda, Isopoda and Tanaidacea in the collections of the Indian Museum. Rec. Indian Mus., 37 : 279-319.

-, 1937. Amphipoda. Sci. Rep. John Murray Exped., 4 (6) : $131-201$.

- , 1940. Contributions to the crustacean fauna of South Africa, 12. Further additions to the Tanaidacea, Isopoda and Amphipoda, together with keys for the identification of the hitherto recorded marine and fresh water species. Ann. S. Afr. Mus., 32 (5) : 381543.

-, 1957. Additions to the fauna list of South African Crustacea. Ann. Mag. nat. Hist., (12) 10 : 1-12.

BATE, C., 1856. On the British Edriopthalma. Rep. 25th Meeting Brit. Assoc. Adv. Sci. : 18-62.

BATE, C. \& J. O. Westwood, 1862. A history of the British sessile eyed Crustacea, 1 (2) : 145-480.

Chevreux, E., 1887. Catalogue des Crustacés Amphipodes marins du Sudouest de la Bretagne, suivi d'un aperçu de la distribution géographique des Amphipodes sur les côtes de France. Bull. Soc. zool. France, 12 : 311.

-, 1901. Crustacés Amphipodes. In: Mission scientifique de M. Ch. Alluaud aux Iles Séchelles (Mars, Avril, Mai, 1892). Mém. Soc. zool. France, $14: 338-438$.

-, 1926. Amphipodes, 1. Gammariens (contd.). In: Voyage de la Goélette Melita aux Canaries et au Sénégal (1889-1890). Bull. Soc. zool. France, 20 : 365-398.

Chevreux, E. \& L. Fage, 1925. Amphipodes. Faune de France, $9: 1-488$.

Chilton, C., 1921. Fauna of the Chilka Lake. Amphipoda. Mem. Indian Mus., 5 : 521-558.

DANA, J. D., 1852. Conspectus crustaceorum quae in orbis terrarum circumnavigatione, Carolo Wilkes e classe
Reipublicae Federate Duce lexit et desciipsit. Pars III subtribus 1. Gammaracea. Proc. Am. Acad. Arts Sci., 2 : $201-220$.

Giles, G. M., 1885. Description of a new species of the amphipod Melita. J. As. Soc. Bengal, $54: 69-71$.

- , 1887. On six new amphipods from the Bay of Bengal. J. As. Soc. Bengal, $56: 212-229$.

Kunkel, B. W., 1910. The Amphipoda of Bermuda. Trans. Connecticut Acad. Arts Sci., $16: 1-116$.

Norman, A. M., 1867. Report of the committee appointed for the purpose of exploring the coast of the Hebrides by means of the dredge, 2. On the Crustacea, Echinodermata, Polyzoa, Actinozoa and Hydrozoa. Rep. 36th Meeting Brit. Assoc. Adv. Sci. : 203.

-, 1869. Shetland and final dredging report, 2. On the Crustacea, Tunicata, Polyzoa, Echinodermata, Actinozoa, Hydrozoa and Porifera. Rep. 38th Meeting Brit. Assoc. Adv. Sci. : 247-336.

Nayar, K. N., 1959. The Amphipoda of the Madras coast. Bull. Madras govt. Mus. (nat. Hist.), 6 (3) : $1-59$.

-, 1965. On the gammaridean Amphipoda of the Gulf of Mannar, with special reference to those of the Pearl and Chank beds. Proc. Symp. Crustacea, 1 : 133-168.

Pillai, N. K., 1957. Pelagic Crustacea of Travancore, 3. Amphipoda. Bull. centr. Res. Inst. Univ. Travancore, 5 (1) : 29-68.

Pirlot, J. M., 1934. Les Amphipodes. Siboga Monogr., 33d : 167-235.

—, 1938. Les Amphipodes. Siboga Monogr., 33f : 329_ 388.

Schellenberg, A., 1925. Crustacea, 8. Amphipoda. Beiträge zur Kenntnis der Meeresfauna Westafrikas, 3 (4) : $114-204$.

-, 1938. Litorale Amphipoden des tropischen Pazifiks. Kgl. Svenska Vetensk. Akad. Hand., (3) $16: 1-105$.

Stebring, T. R. R., 1888. Report on the Amphipoda collected by H.M.S. "Challenger" during the years 1873-1876. Rep. sci. Res. Voy. H.M.S. Challenger, (Zool.) 29 : i-xxiv + 1-1737.

-, 1906. Amphipoda, 1. Gammaridea. Tierreich, 21 : $1-806$.

-, 1910. Crustacea, 5. Amphipoda. In: Scientific research on the trawling expedition of H.M.C.S. "Thetis". Mem. Australian Mus., 4 (2) : 565-658.

WALKer, A. O., 1904. Report on the Amphipoda collected by Prof. Herdman at Ceylon, in 1902. Rep. Ceylon Pearl Oyster Fisheries, Suppl. Rep., 17 : 229 300.

Wigley, R. L., 1966. Two new marine amphipods from Massachusetts, U.S.A. Crustaceana, 10 (3) : 259270. 